\title{
الفكر المقاصدي في الشريعة الإسلامية ومواجهة الإرهاب
}

\section{وكتؤ/ مaالق مدهد مaالق الهمليريا}

الأستاذ المساعد بأكاديمية سعد العبد الله للعوم الأمنية

الكويت

\section{مستخلص البحث}

الحمد لله و الصلاة و السلام على رسول الله صلى الله عليه وسلم، وبعد: بلقي البحث الضوء على أثز المقاصد الضرورية الخمسة في مواجهة ظاهرة انتشرت في كثير من الدول، تلك الظاهرة هي الإزهاب، وجعلت عنوانه 》الفكر هو المقاصدي في الثريعة الإسلامية ومو اجهة الإزهابه

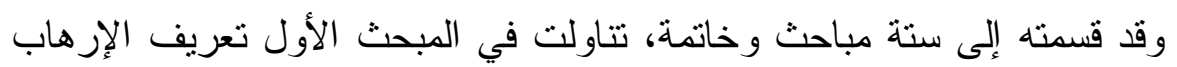

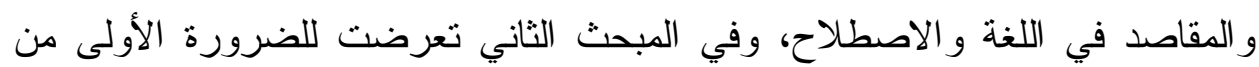

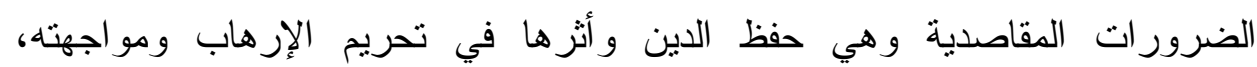
وتعرضت في المبحث الثالث للضرورة الثانية من تللك المقاصد وهي حفظ النفس هن وبينت أثز ها في مو اجهة الإرهاب وتحريمه، ثم تعرضت في المبحث الر ابع للضرورة

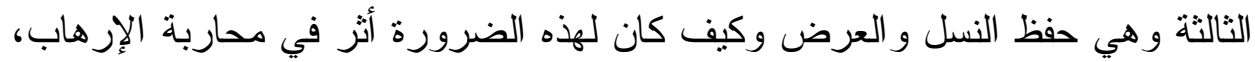
ثم تعرضت في المبحث الخامس للضرورة المقاصدية الر ابعة وهي حفظ العقل وأثرها في تحريم الإرهاب، ثم ختمت المباحث بالمبحث السادس وتتاولت فيه الضرورة الخامسة و الأخيرة من الضروريات الخمسة المقاصدية وأثرها في محاربة الإرهاب وتحريمه، ثم ختمت البحث بخاتمة بينت فيها أهم ما توصلت إليه من نتائج من مادة

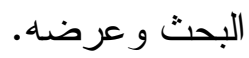

وصلى الله على محمد و على آله وصحبه وسلم تسليما كثير ا. 


\section{مقدمة:}

إن الحمد لله نحمده ونستعينه ونستهديه ونستغفره ونعوذ باله من شرور أنفسنا ومن سيئات أعمالنا إنه من بهذه الله فهو المهتد ومن بضلل فلن تجد له وليا مرشدا. وبعد:

قال تعالى: \}يا أيها الذين آمنوا اتقو الله حق تقاته ولا تموتن إلا و أنتم مسلمون\{

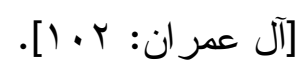

وقال: جيا أيها الناس اتقو ال ربكم الذي خلقكم من نفس واحدة وخلق منها زوجها وبث منهما رجالا كثير ا ونساء واتقو الهه الذي تساءلون به و الأرحام إن اله كان عليكم رقيبا\{ [النساء: 1 ]

وقال: جيا أيها الذين آمنو ا اتقو الله وقولوا قو لا سديدا يصلح لكم أعمالكم ويغفر

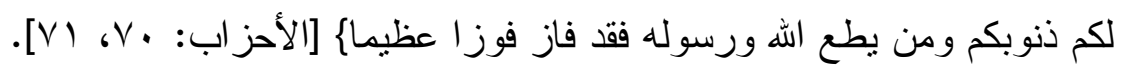
أما بعد:

فإن أصدق الحديث كتاب الله، وخير الهدي هدي محمد صلى الله عليه وسلم، وشر الأمور محدثاتها، وكل محدثة بدعة، وكل بدعة ضلالة،، وكل ضلالة في النار .

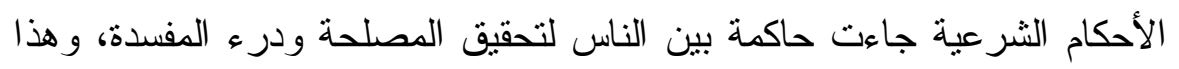

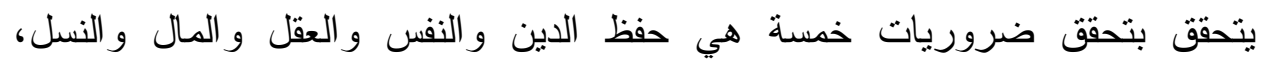

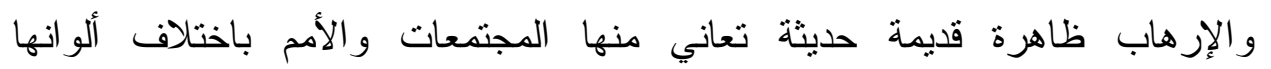

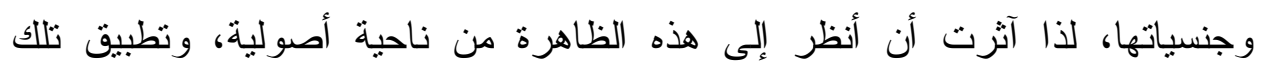

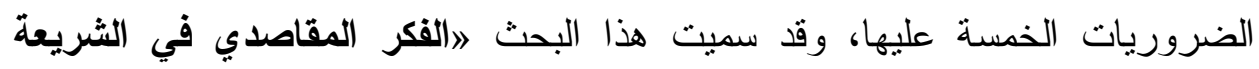

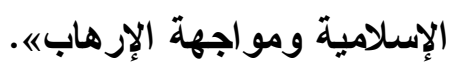

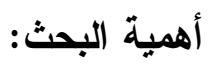

تثمثل أهمية البحث في الفكر المقاصدي عامة في معرفة مدى توافق القضايا المطروحة على الساحة العالمية عامة والعربية و الإسلامية خاصة مع مقاصد النشريع الإسلامي الذي هدف إلى تحقيق المصالح العامة و الخاصة ودرء كافة أثنكال المفاسد. أما أهمية البحث هنا- على وجه الخصوص- في معرفة ما أقرته مقاصد التشريع الإسلامي في قضية معاصرة أرقت الأمم و المجتمعات وسلبتها أمنهم

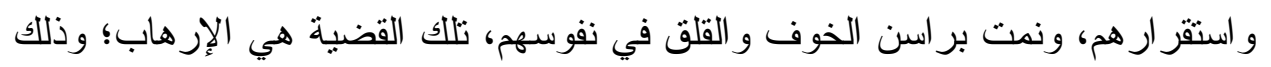


لبيان كيف أن الأصول التشريعية في الإسلام قد نفت الإرهاب، وردت قول كل من ألصق تلك التهمة بالإسلام، ودحضت حجة من تمسك بالإرهاب وجعله أصلا شرعيا

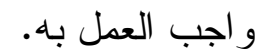

أهد (ف البحث: - أبه: هدفت من در اسة الفكر المقاصدي ومواجهته للإز هاب عدة أهداف هي:

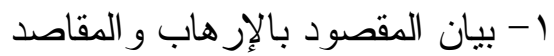
r- بيان أثز حفظ الدين في تحريم الإرهاب ومو اجهته ب- بيان أثز حفظ النفس في تحريم الإرهاب ومو اجهته ـ - بيان أثز حفظ النسل و العرض في تحريم الإرهاب ومو اجهته 0- بيان أثز حفظ العقل في تحريم الإرهاب ومو اجهته 1- بيان أثز حفظ المال في تحريم الإرهاب ومو اجهته تساؤلات البحث: جاء البحث إجابة لكثير من التساؤلات تثمثل في 1- ما المقصود بالإز هاب و المقاصد؟ r- ما أثز حفظ الدين في تحريم الإرهاب ومحاربته بالِ هابه ץ- ما أثز حفظ النفس في تحريم الإرهاب ومحاربته؟

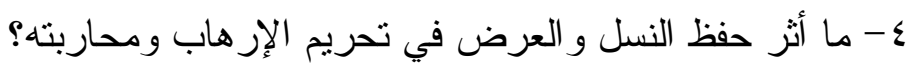
ه- ما أثز حفظ العقل في تحريم الإرهاب ومحاربته؟

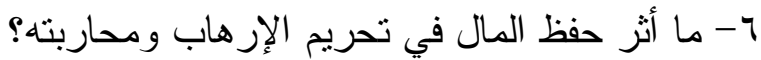

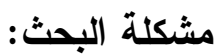
تتمثل مشكلة البحث في محاولة تطبيق المقاصد الثرعية على موضوع ذاع

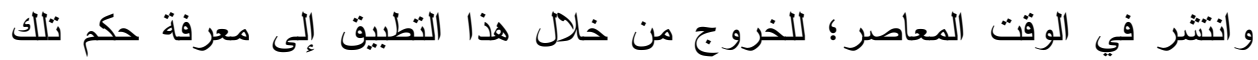
الأفعال، ومدى تو افقها مع التشريع الإسلامي من عدمهـ

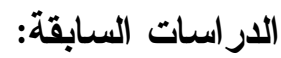
لم أقف فيما وققت عليه على دراسة تتاولت أثز المقاصد الثرعية في محاربة الإرهاب، ولكن كثرت المؤلفات و الدر اسات حول المقاصد الشرعية ومن أثنهر ها كتاب

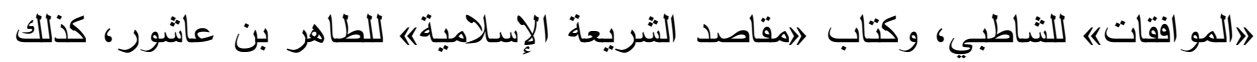


كثرت الدراسات حول موضوع الإرهاب من الوجهة الثرعية، ومن أبرز تلك فئك

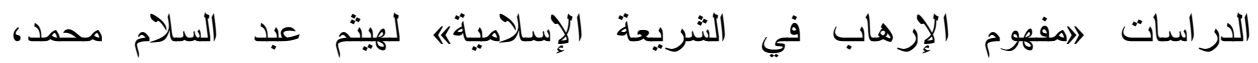

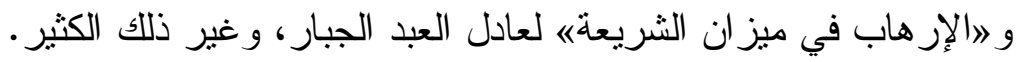

اقتضت طبيعة البحث أن أسلك فيه المنهج الوصفي التحليلي الاستقرائي

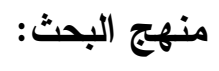
الاستتباطي. خطة البحث:

تتاولت البحث في مقدمة وستة مباحث وخاتمة وقائمة مصادر ومر اجع، بيانها

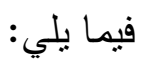
المقدمة: تتاولت فيها أهمية البحث، و أهدافه، وتساؤلاته، ومشكلته، و الدر اسات السابقة عليه، ومنهجه، وخطته.

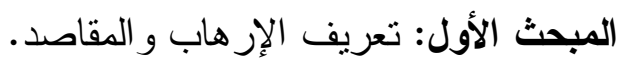

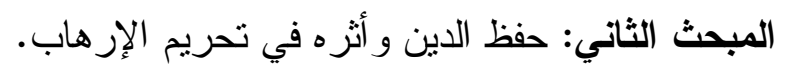
المبحث الثالث: حفظ النفس و أثره في تحريم الإرهاب.

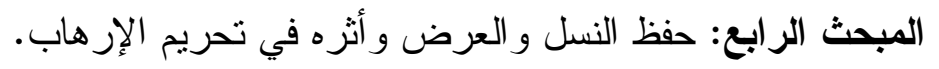
المبحث الخامس: حفظ العقل و أثزه في تحريم الإرهاب. المبحث السادس: حفظ المال وأثزه في تحريم الإرهاب.

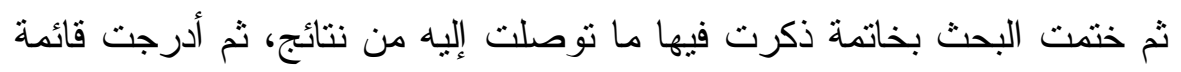
بالمصادر و المر اجع التي اعتمدت عليها في جمع مادة البحث. وصلى الله على محمد و على آله وصحبه وسلم تسليما كثير ا. 


\section{المبحث الأول}

تعريف الإرهاب والمقاصد

\section{أولا: تعريف الإرهاب لغة واصطلاحا:} أ- تعريف الإرهاب لغة: الإن

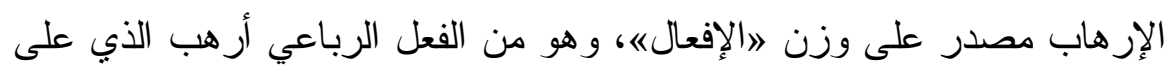

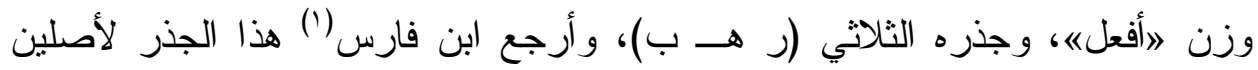

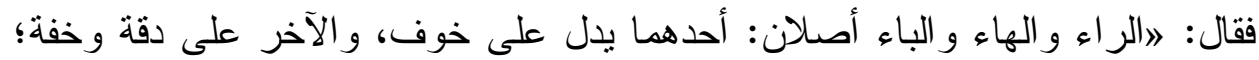

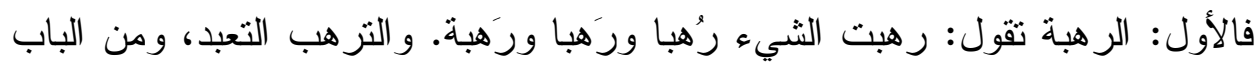
الإزهاب وهو قدع الإبل من الحوض وضن وذيادها. و الأصل الآخر: الرَّهب الناقة المهزولة، وهن والرِّهاب الرِّقاق من النصال و واحدها رهب، و الرهاب عظم في الصدر مشرف على البطن منل اللسانه(؟).

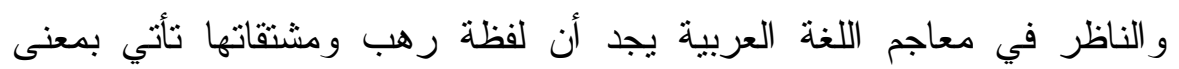

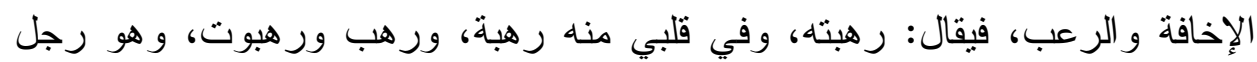

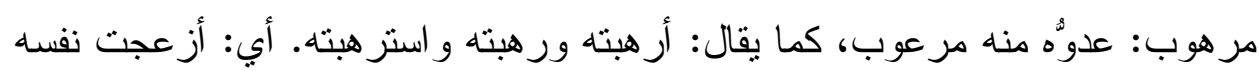

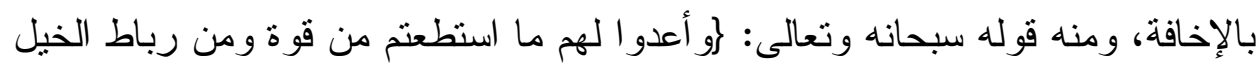

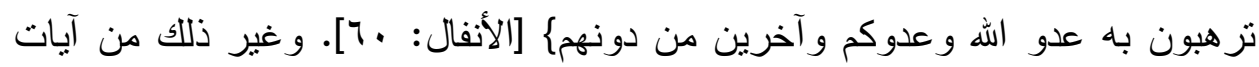
القر آن التي دلت على هذا المعنى ().

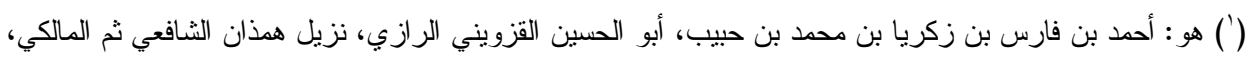

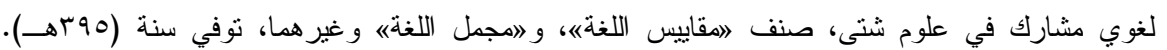

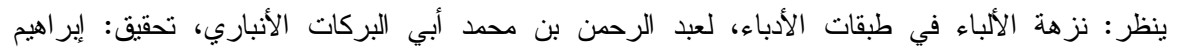

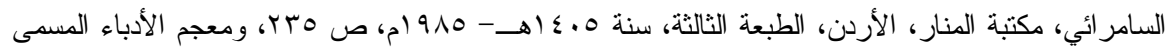

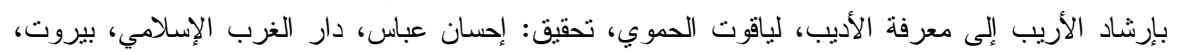

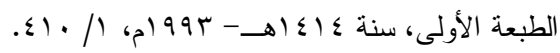

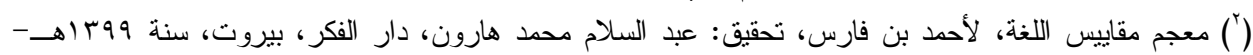

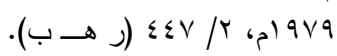

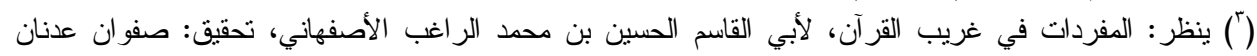

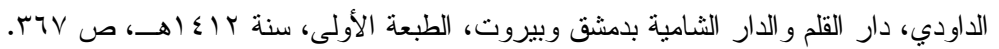




\section{ب- تعريف الإرهاب اصطلاحا:}

تعددت التعريفات الاصطلاحية للإزهاب، ولكن آثرت أن أسوق تعريف مجمعين

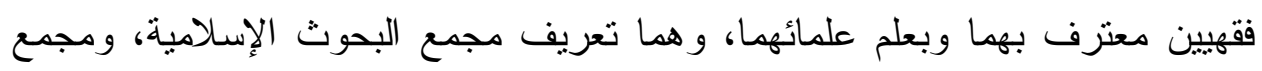
الفقه الإسلامي بمكة، وبيان ذللك فيما يلي: أولا: تعريف مجمع البحوث الإسلامية بالأزهر الثريف بالقاهرة عرف عرف الإرهاب

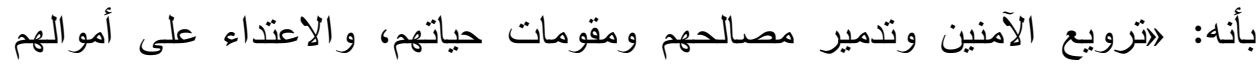

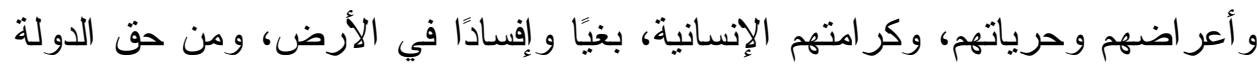

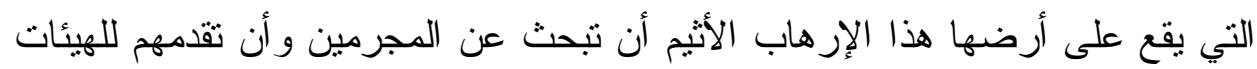
القضائية؛ لكي تقول كلمتها العادلة بشأنهمه" ('). ثانيا: تعريف مجمع الفقه الإسلامي التابع لر ابطة العالم الإسلامي بمكة المكرمة

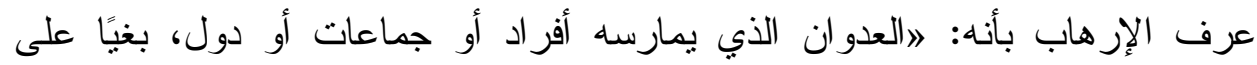
الإنسان - دينه ودمه و عقله و ماله- بغير حق، ويشمل صنوف التخويف والأنه وأذى و التهديد

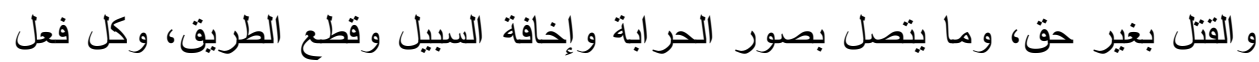

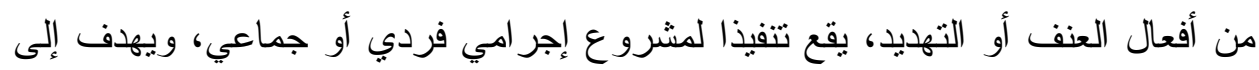
إلقاء الرعب بين الناس أو تريعهم بايذائهم أو تعريض حياتهم أو حريتهم أو أمنهم أو أو

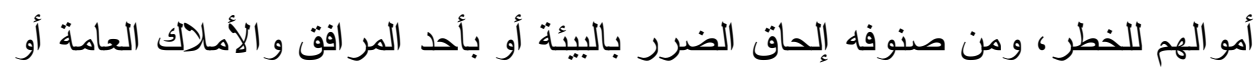

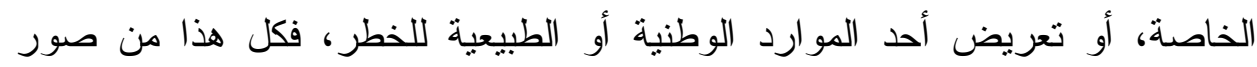

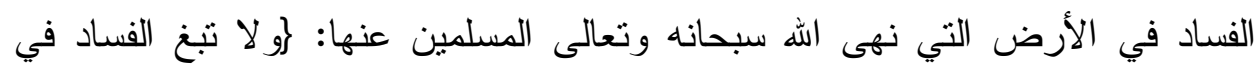

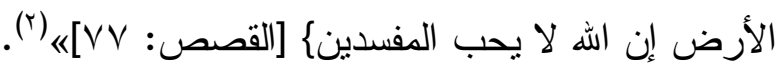

(') بيان مجمع البحوث الإسلامية بالأزهر الثريف بشأن ظاهرة الإرهاب، والمنشور بمجلة الفرقان، بالمغرب، العدد V V 9 .

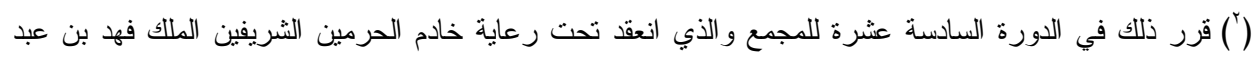

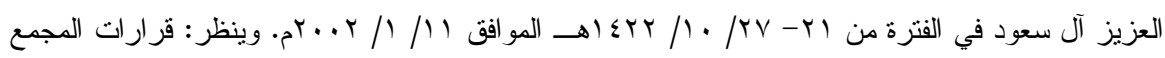

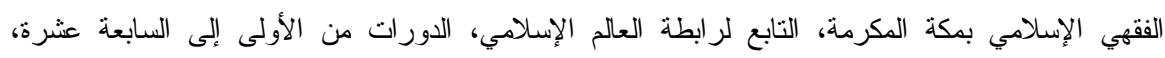

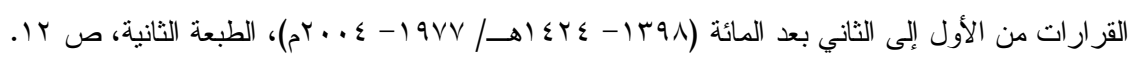




\section{ثانيا: تعريف المقاصد: \\ أ- تعريف المقاصد لغة: تصنة:}

المقاصد لغة: جمع تكسير مفرده مقصد، الذي أصله من الفعل الثثلاثي الصحيح

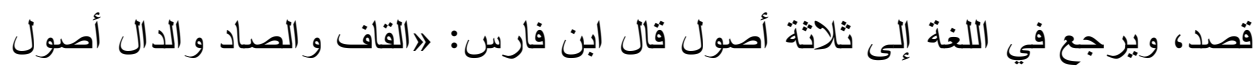

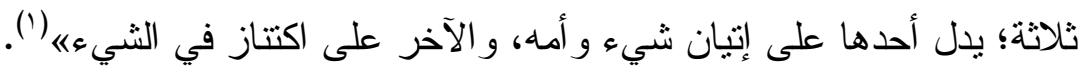

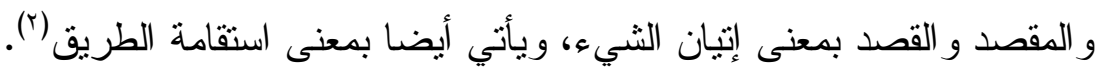

\section{ب- تعريف المقاصد اصطلاحا:}

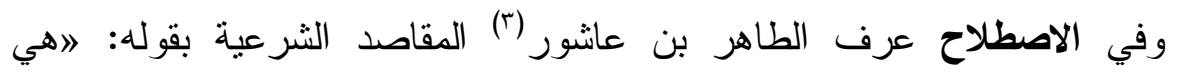

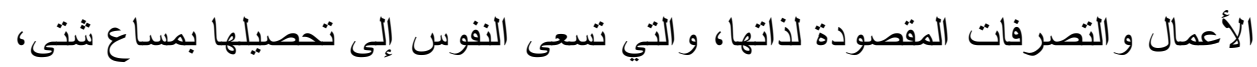
أو تحمل على السعي إليها امتثالاه(ء).

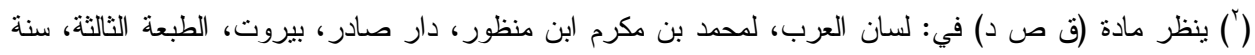

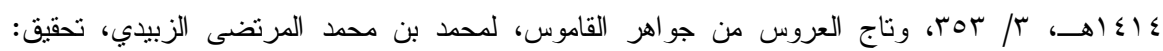

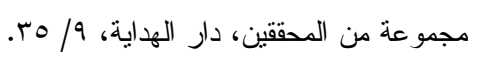

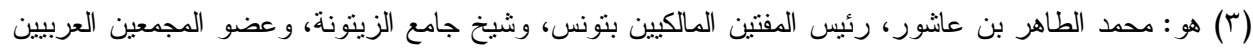

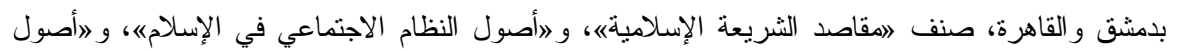

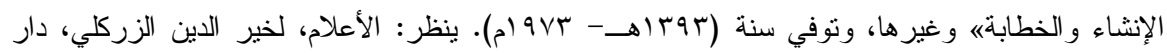




\section{المبحث الثاني \\ حفظ الدين وأثره في تحريم الإرهاب}

تقديم في الضروريات المقاصدية:

قد بيَّنَ الكتاب و السنة للناس التكاليف الثرعية و المقاصد التي تهدف إليها هذه التكاليف، وهذه المقاصد قد بينها الإمام الثاطبي (') في قوله: التكاليف الثريعة ترجع إلى حفظ مقاصدها في الخلق، و هذه المقاصد لا تعدو ثلاثة أقسام: أحدها: أن تكون ضرورية، والثاني: أن تكون حاجية، والثالث: أن تكون تلاتهامن تحسينية.

فأما الضرورية فمعناها أنها لا بد منها في قيام مصالح الدين و الدنيا، بحيث إذا

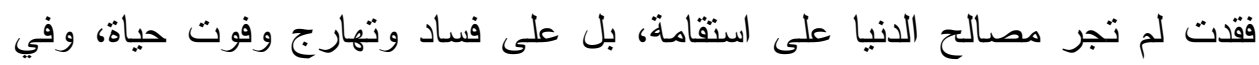
الأخرى فوت النجاة والنعيم، و الرجوع بالخسران المبين، و الحفظ لها يكون بأمرين:

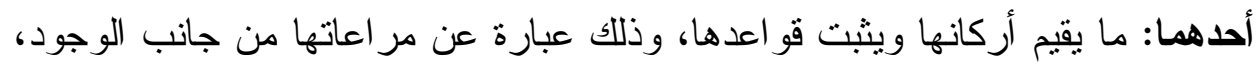

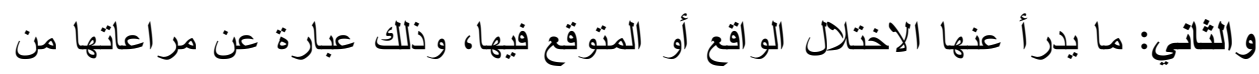

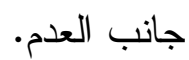

فأصول العبادات راجعة إلى حفظ الدين من جانب الوجود، كالإيمان و النطق

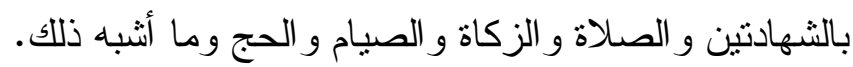

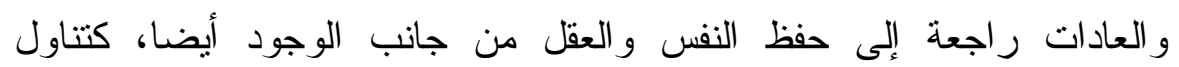

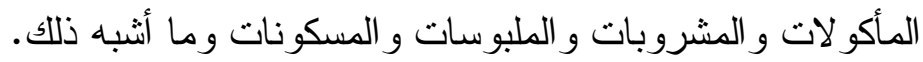
و المعاملات راجعة إلى حفظ النسل و المال من جانب الوجود، و إلى حفظ النفس ونس والى و العقل أيضا، لكن بو اسطة العادات. و الجنايات ويجمعها الأمر بالمعروف و النهي عن المنكر، ترجع إنى إلى حفظ الجميع

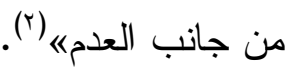

(') هو : إبر اهيم بن موسى بن محمد اللخمي الغرناطي المالكي الثاطبي، أبو إسحاق، محدث فقيه أصولي لغوي مفسر،

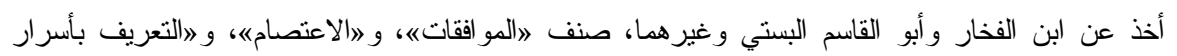

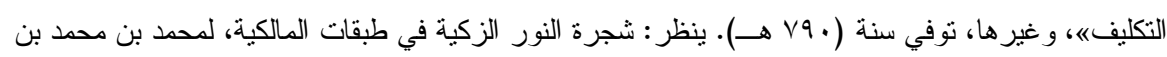

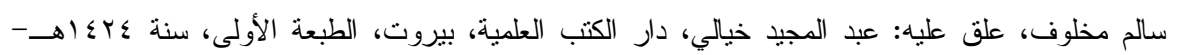

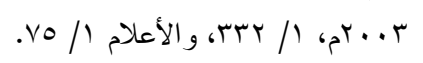

(Y) المو افقات، لإبر اهيم بن موسى الثناطبي، تحقيق: أبو عبيدة مشهور بن حسن آل سليمان، دار ابن عفان، الطبعة 


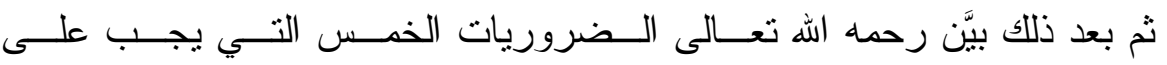

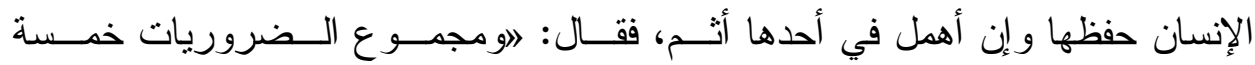

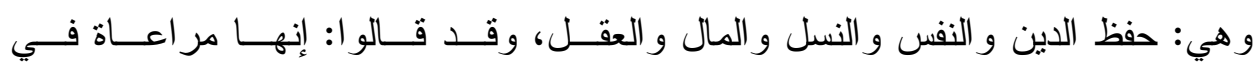

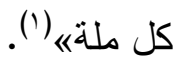

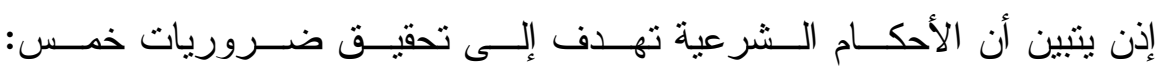

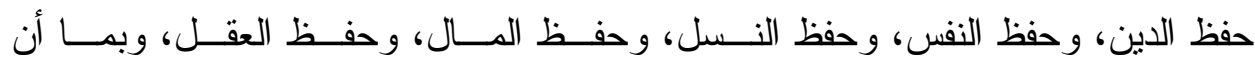

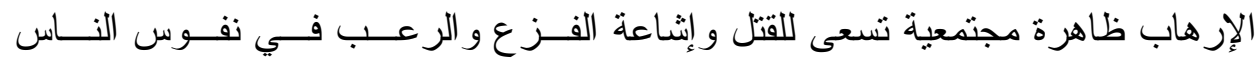

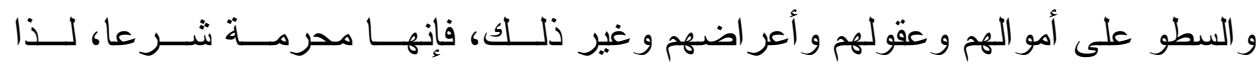

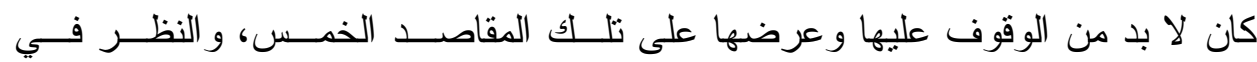
أثر تلك المقاصد في تحديد الحكم الثرعي للإِرهاب، وبيان ذلك فيما يلي:

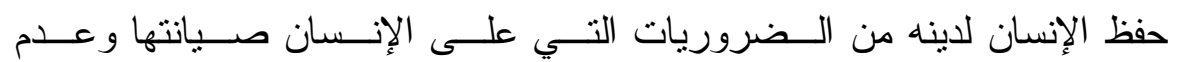

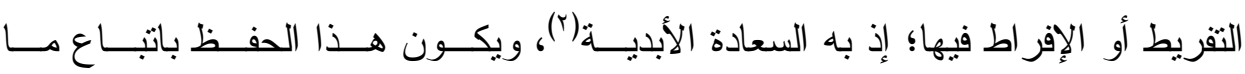

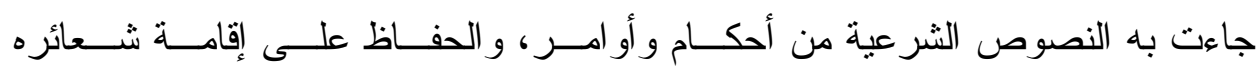

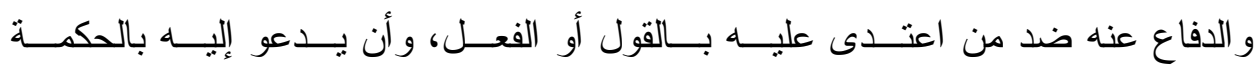

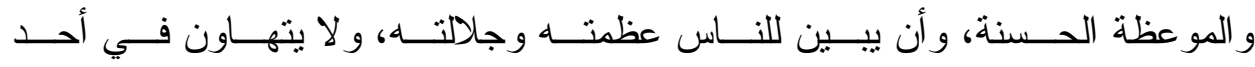

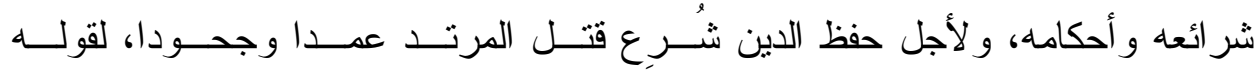

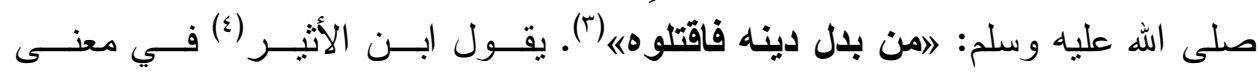
هذا الحديث: الهن خرج من الإسـلام إلى غيره لا من خــرج مــن ديـن غيــر ديـن

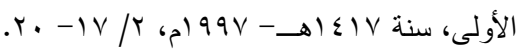

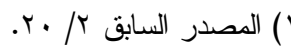

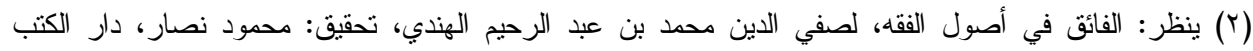

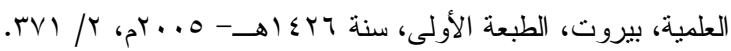

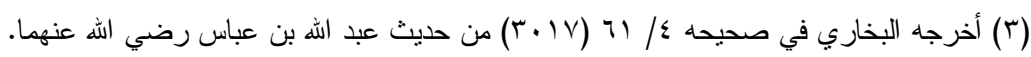

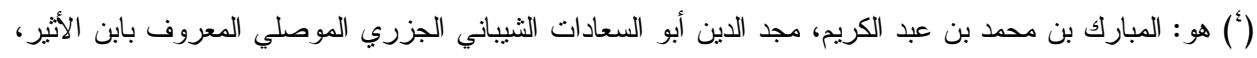

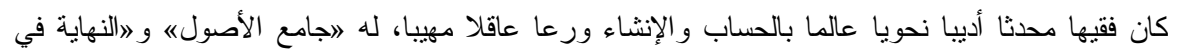

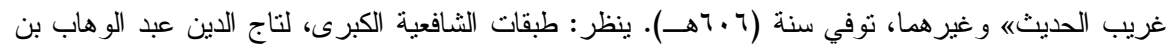

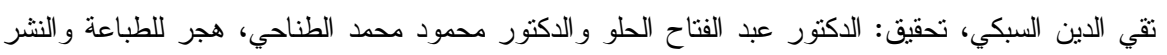

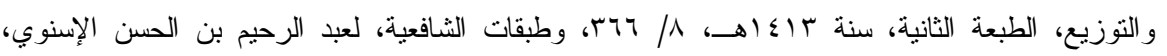

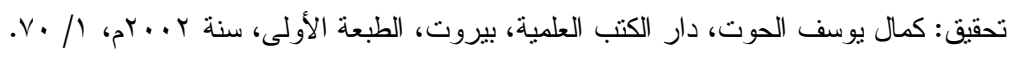


الإسـام إلى غيره، كمن يخرج من بهودية إلـى نــصر انية أو مجوســية، ومسـن فعـل ذلك من أهل الذمة لم يستتب ولم يقتلها' ('). ولحفظه أيضا شرع قتال الكفار وجهادهم بالضوابط الثرعية التي وضعتها النصوص الثرعية، لقوله سبحانه وتعالى: (قاتلوا الذين لا يؤمنون بالهة [التوبة: وجب].

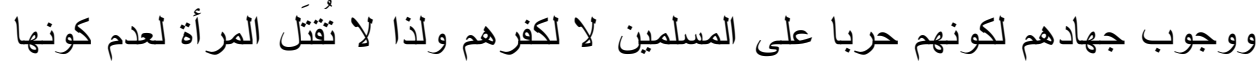

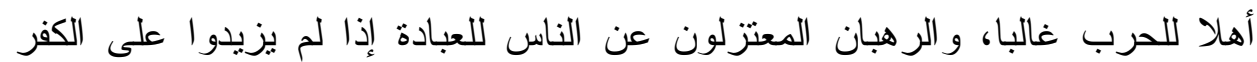

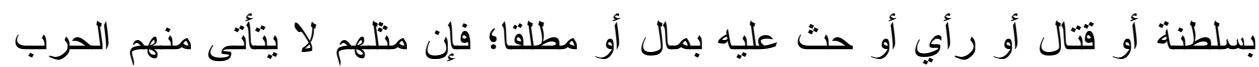
غالبا(r) ولحفظه أيضا حرم البدعة و الابتداع بالزيادة والنقصان في الأحكام الثرعية على

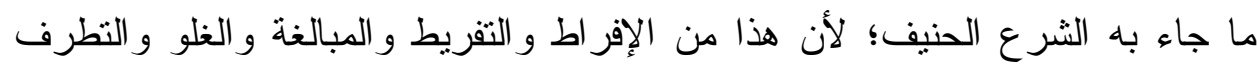

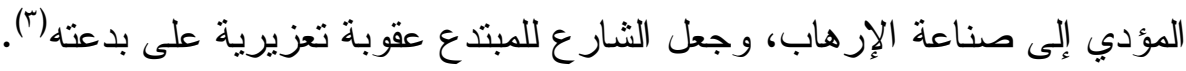
وحفظ الدين لا يبيح قتل الذمي- اليهودي و النصر اني- و ولا قتاله ما لم يكن حربيا

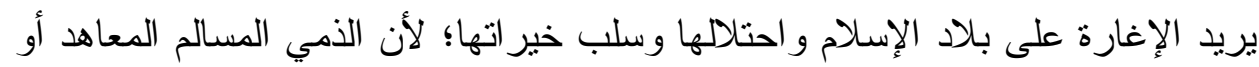

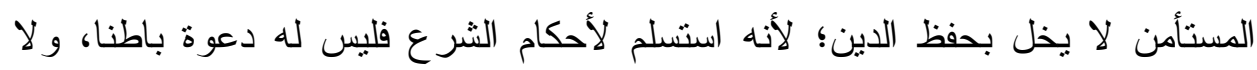
شوكة ظاهر ا يفسد على الناس دينهم (๕). وبناء على ما أوردته هنا يتضح أن حفظ الدين - كما ذكر الثاطبي-: النهاصله

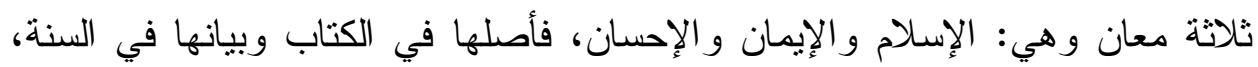

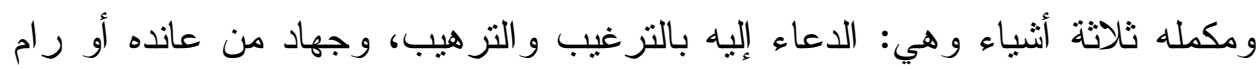

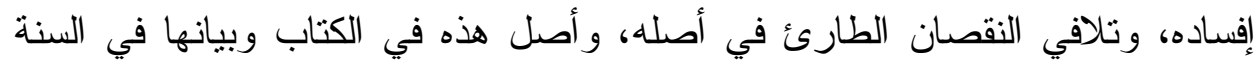
على الكماله (ن).

(') الثافي في شرح مسند الثافعي، لمجد الدين أبي السعادات المبارك بن محمد بن الأثير، تحقيق: أحمد بن سليمان وأبي تميم ياسر

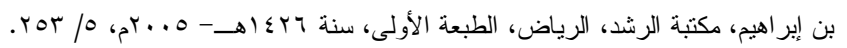

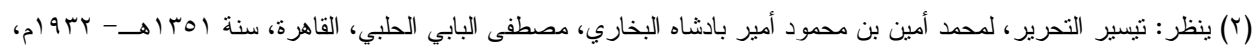
T. T/ T (r) ينظر : شرح الكوكب المنير ، لنقي الدين محمد بن أحمد ابن النجار الحنبلي، تحقيق: محمد الزحيلي ونزيه حماد، مكتبة العبيكان،

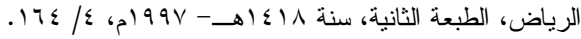

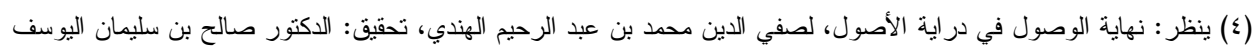

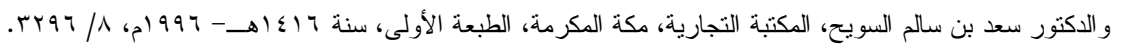


و الإرهاب نتيجة طبيعية للنطرف الفكري و الغلو في المفاهيم و الأحكام الثرعية،

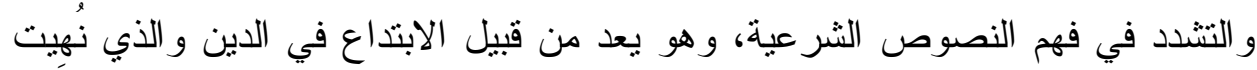

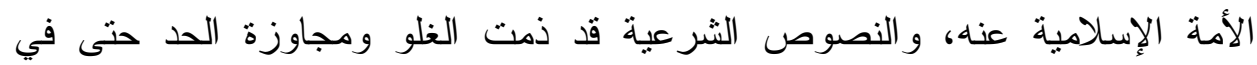
الطاعات، وقد ذكرنا قريبا بعضا من تللك النصوص التي حضت على التيسير بما

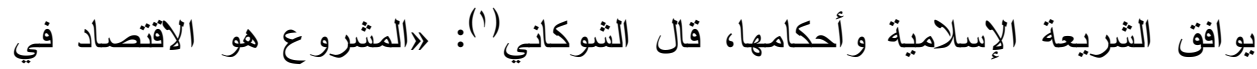

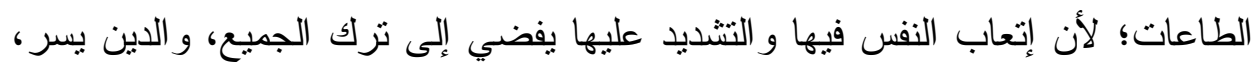

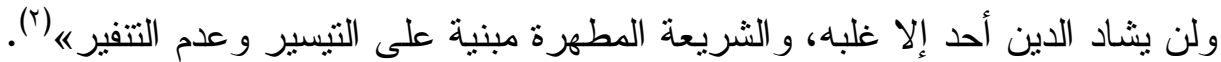

(1) هو: محمد بن علي بن محمد الثوكاني، فقيه مجتهد من كبار علماء صنعاء اليمن، وقاضيها، له مصنفات كثيرة

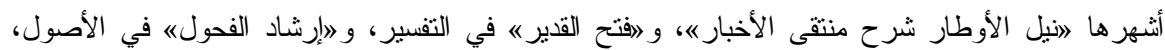

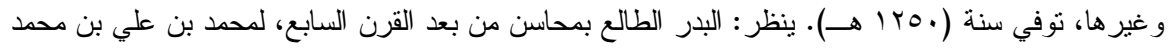

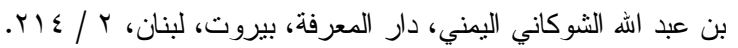

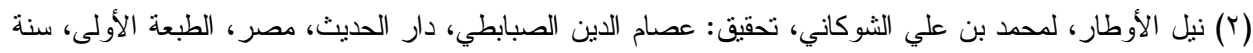

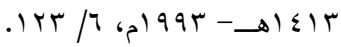




\section{المبحث الثالث}

\section{حفظ النفس وأثزه في تحريم الإرهاب}

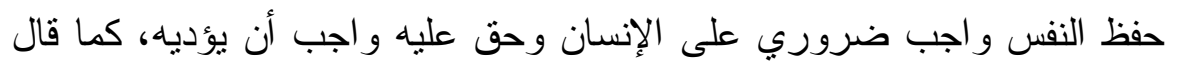

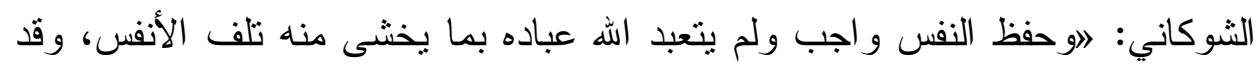

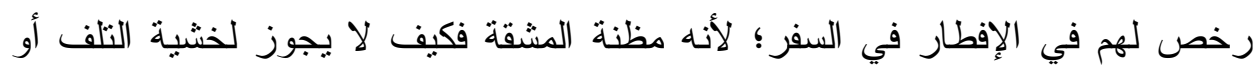

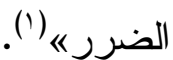

و الإحسان إلى النفس وتجنيبها الهلاك من حفظها وأداء حقها، وكذلك توفير كل

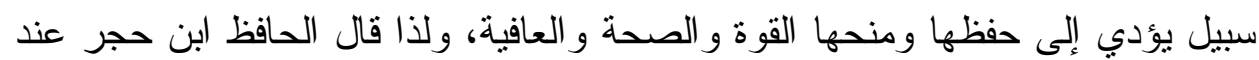

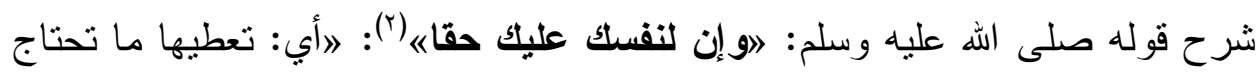
إليه ضرورة البشرية مما أباحه الله للإنسان من الأكل و الثرب والنه والراحة التي يقوم بهاها بدنه؛ ليكون أعون على عبادة ربه، ومن حقوق النفس قطعها عما سوى الله تعالى، لكن الن النه ذللك يختص بالتعلقات القلبيةه (r). وقال الطاهر بن عاشور أيضا: لهفظ النفس صيانتها من التلف أفرادًا

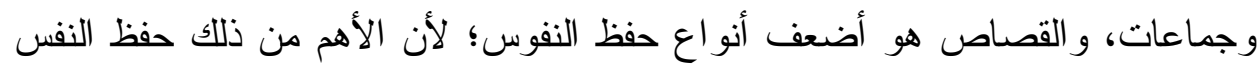

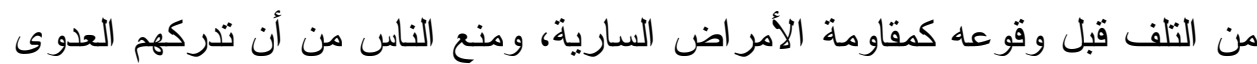
بدخول بلد قد انتشرت فيه أوبئةة (؛).

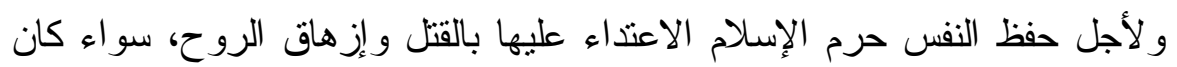

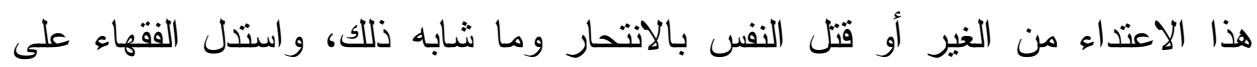

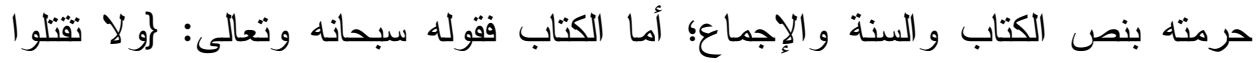
النفس التي حرم الله إلا بالحق ذلكم وصاكم به لعلكم تعقلون\{ [الأنعام: 101 10]. وقوله:

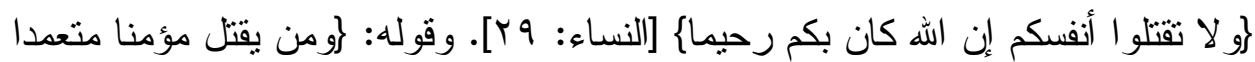

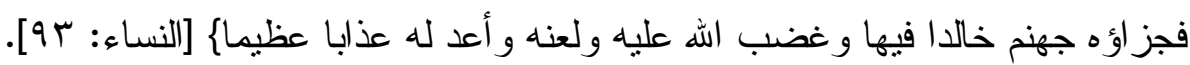

(') السيل الجرار المتدفق على حدائق الأزهار، لمحد بن علي الثوكاني، دار ابن حزم، بيروت، الطبعة الأولى،

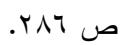

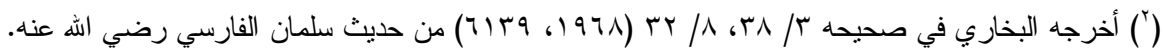

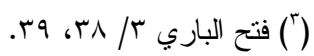

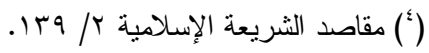


و أما السنة فقد جعل النبي صلى الله عليه وسلم قتل النفس بغير حق من الكبائر

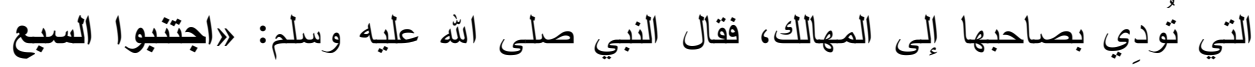

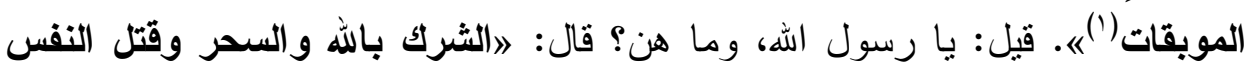
التي حرم الله إلا بالحق...ی) (؟).

وقال أيضا لبيان عظمة حرمة قتل النفس: الن بالن يزال المؤمن في فسحة من دينه ما لم يصب دما حر اماه (). وقال عبد الله بن عمر رضي الله عنه: إن من ورطات الأمور التي لا مخرج

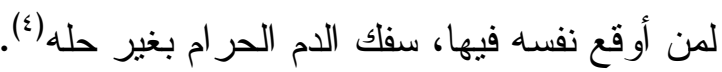

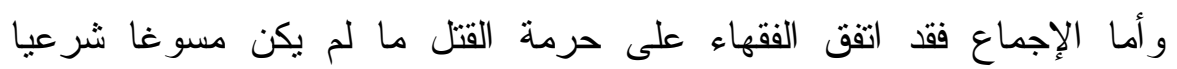
كالقصاص أو المرتد عمدا أو ما نص عليه الثنارع الحكيم و أباحه( وقد اختلف الفقهاء الأربعة في تقسيم القتل كالتالي: أولا: تقسيم فقهاء الحنفية:

اختلف فقهاء الحنفية في تقسيم القتل على ثلاثة أقوال:

القول الأول: أن القتل ثلاثة أقسام: قتل العمد، وقتل الخطأ، وقتل شبه العدد آنه القول الثاني: القتل أربعة أقسام: قتل العمد، وقتل الخطأ، وقتل شبه العدد، وقتل وقل العتل في معنى الخطأ)(V)

(1) الموبقات: الذنوب المهكات. النهاية في غريب الحديث والأثر ، لمجد الدين المبارك بن محمد ابن الأثير، تحقيق: طاهر

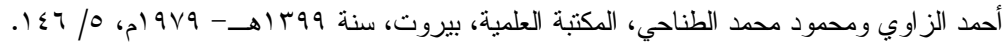

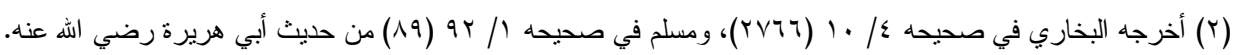

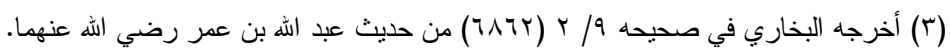

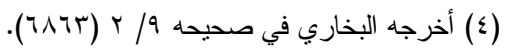
() ينظر: المغني، لموفق الدين عبد الله بن أحمد ابن قدامة المقسي، تحقيق: الدكتور عبد الله بن عبد المحسن التركي

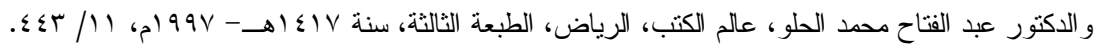

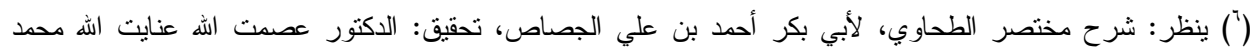

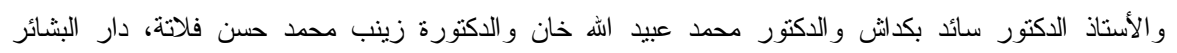

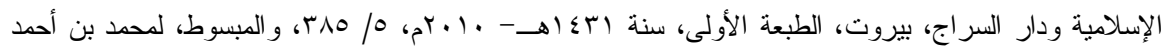

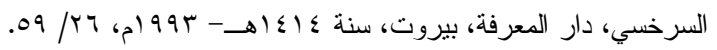
(") ينظر : بدائع الصنائع في ترتيب الثر ائع، لعلاء الدين أبي بكر بن مسعود الكاساني، دار الكتب العلمية، بيروت، الطبعة

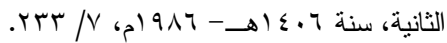


القول الثالث: القتل خمسة أقسام: قتل العمد، وقتل الخطأ، وقتل شبه العمد، وقتل

أجري مجرى الخطأ، و القتل بسبب، ونسبوا هذا القول لأبي بكر الجصاص الرازي|' (').

\section{ثانيا: تقسيم فقهاء المالكية:}

اتفق فقهاء المالكية على أن أقسام القتل اثنان هما: قتل العمد، وقتل الخطأ،

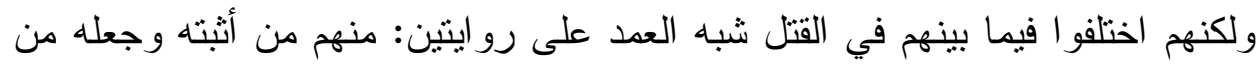

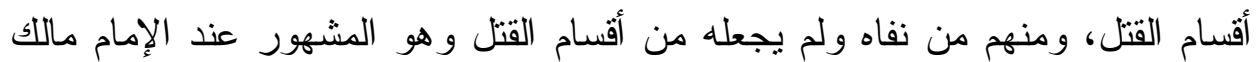
رحمه الله تعالى (r).

\section{ثالثا: تقسيم فقهاء الثافعية:}

اتفق فقهاء الثافعية على أن أقسام القتل ثلاثة: قتل العدد، وقتل الخطأ، وقتل شبه

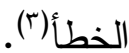

\section{رابعا: تقسيم فقهاء الحنابلة:}

اختلف فقهاء الحنابلة في أقسام القتل على قولين:

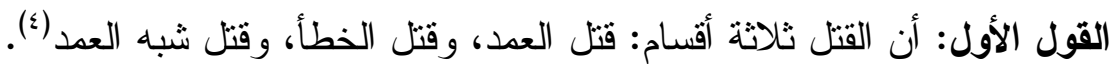
القول الثاني: أن القتل أربعة أقسام: قتل العدد، وقتل الخطأ، وقتل شبه الخده العمد، وقتل أجري مجرى الخطأ(0).

(') ينظر: المبسوط بr/ 09، وتبيين الحقائق شرح كنز الدقائق، لفخر الدين عثمان بن علي الزيلعي، المطبعة الكبرى

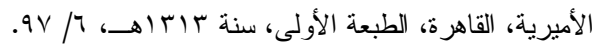

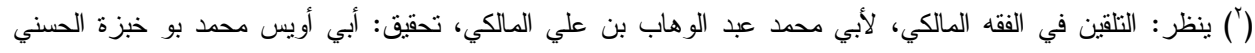

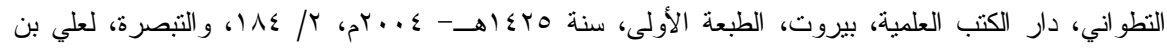

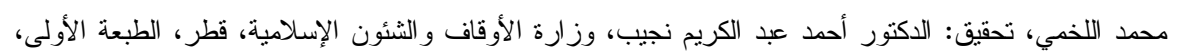

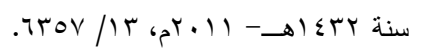

() ينظر: اللباب في الفقه الثافعي، لأحمد بن محمد المحاملي، تحقيق: عبد الكريم بن صنيتان العمري، دار البخاري، المدينة

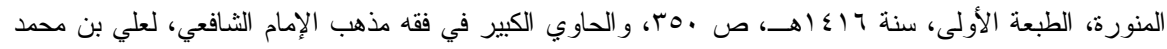

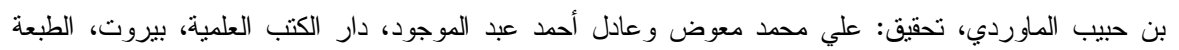

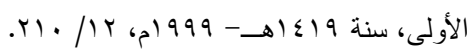

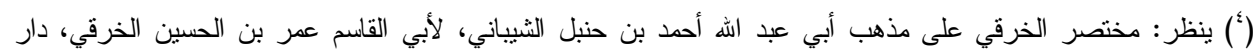

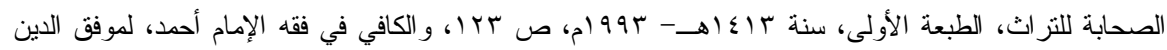

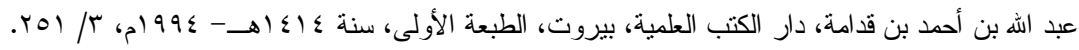

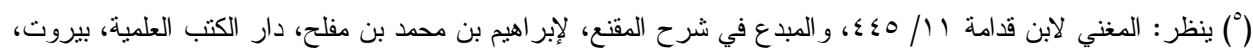

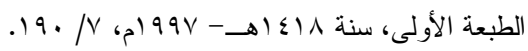




\section{خلاصة ما اختلف فيه الفقهاء حول تقسيم القتل:}

تبين مما قدمناه من آر اء المذاهب الفقهية الفهاء هول في تقيميم القتل الآتي: أولا: اتقق الفقهاء الأربعة على أن القتل العمد والقتل الخطأ من أقسام القتل. ثانيا: اتفق الثافعية وبعض و الحنفية والمشهور عند الحنابلة أن القتل العدد و القتل

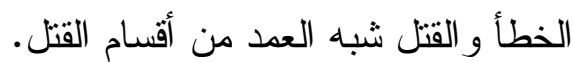

ثالثا: اتفق بعض الحنفية وقول عند الحنابلة أن القتل الذي أجري مجرى الخطأ أحد أقسام القتل. - أقا: رابعا: تقرد بعض الحنفية بزيادة قسم من أقسام القتل لم يذكره غيرهم من فقهاء

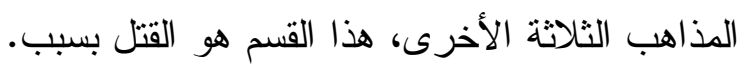

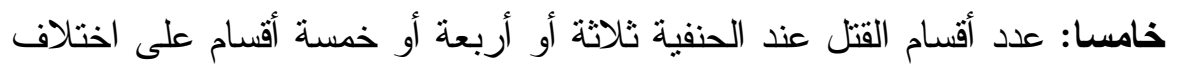

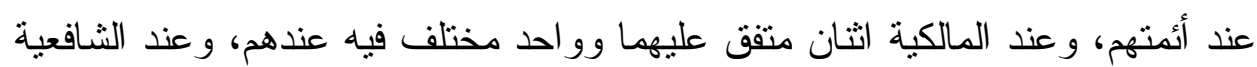

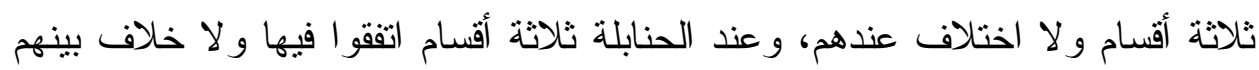
عليها وز اد بعض أئمتهم قسما ر ابعا. وقد جعل الثارع الحكيم على القاتل عقوبات مقدرة في الثريعة الإسلامية، و العقوبات في الثريعة الإسلامية نو عان: الأول: عقوبات مقدرة شر عا وهي الحدود.

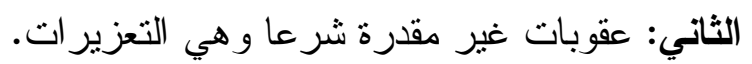

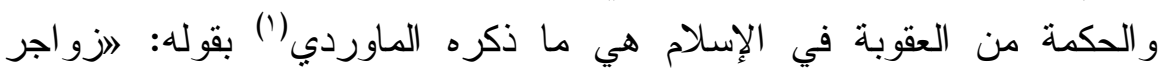

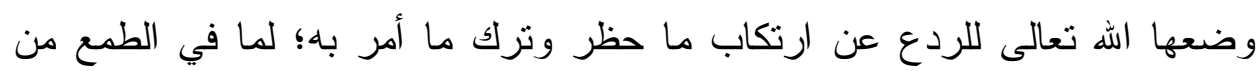

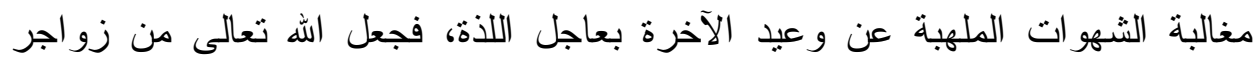

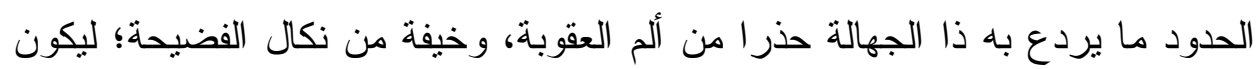

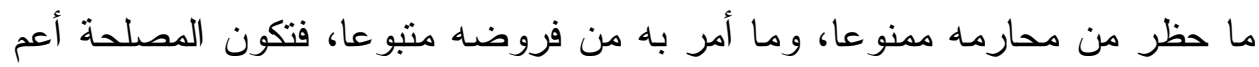

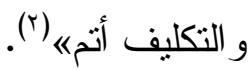

(1) هو : علي بن محمد بن حيب، أبو الحسن الماوردي القاضي، أحد أصحاب الوجوه في المذهب الثافعي، روى عن الحسن

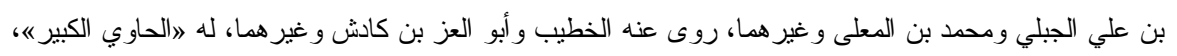

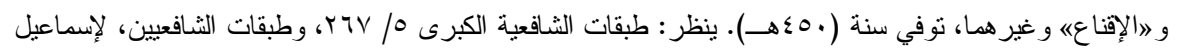

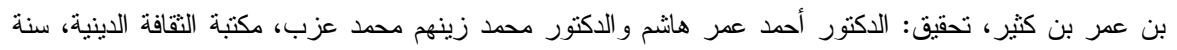


أما عن عقوبة القتل فتختلف تبعا لاختلاف نوع القتل، وبيان ذلك كالتالي: أولا: عقوبة القتل العمد:

قد تكون قصاصا أو دية أو كفارة أو تعزير ا، وبيان تللك العقوبات فيما يلي: أولا: القصاص:

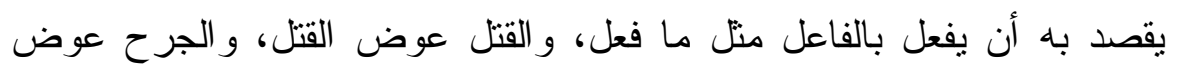

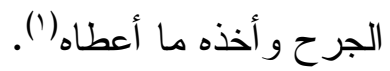
و القصاص ثابت بالكتاب و السنة و الإجماع، أما الكتاب فقوله سبحانه وتعالى : لياه

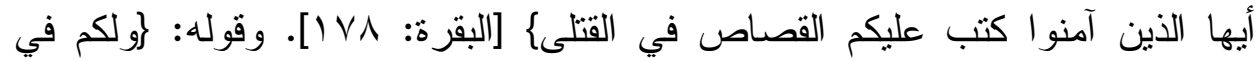

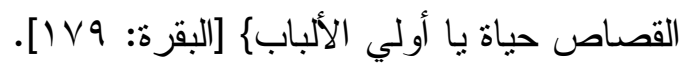

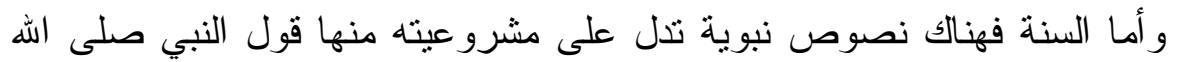
عليه وسلم: اومن قتل عمدا فهو قود، ومن حال بينه وبينه فعليه لعنة الله والملانكة

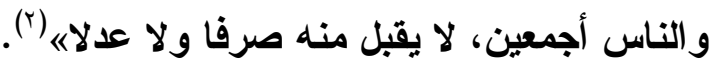

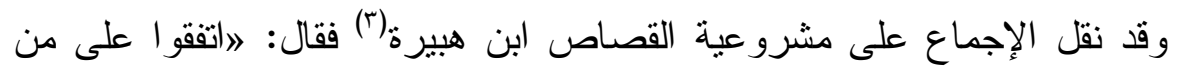

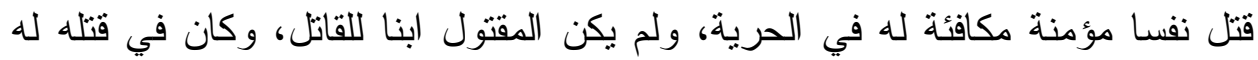

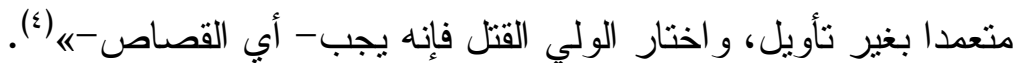

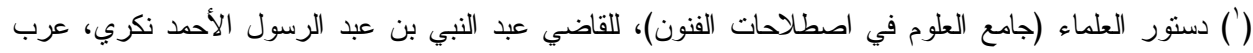

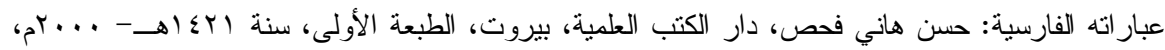
.01/

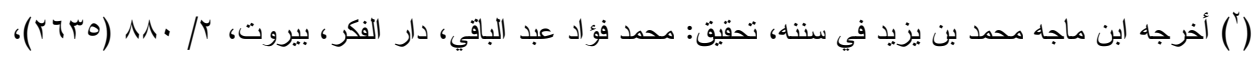

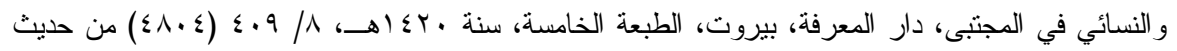

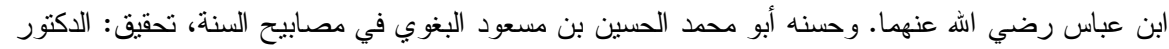

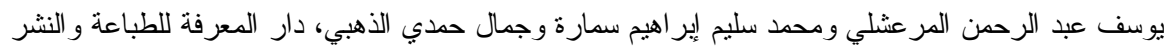

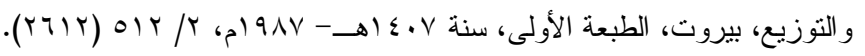

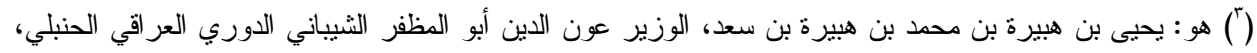

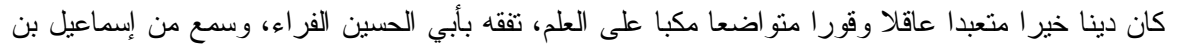

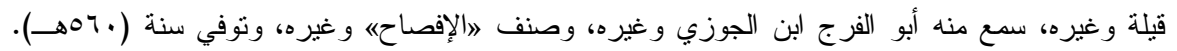

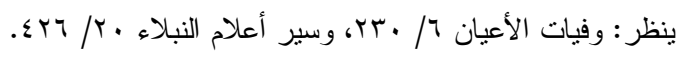

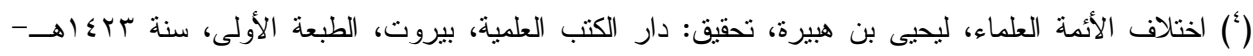

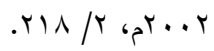




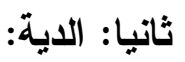

ويقصد بها في الثرع أنها اسم للمال الذي هو بدل للنفس (').

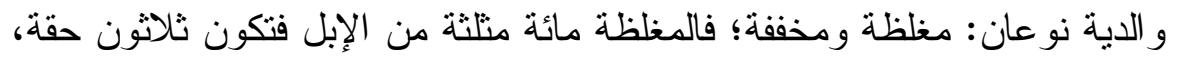
وثلاثون جذعة، وأربعون خلفة في بطونها أو لادها.

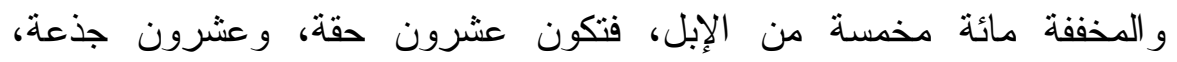

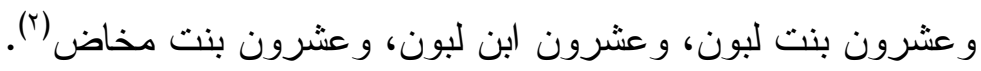

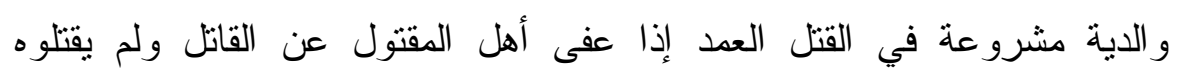

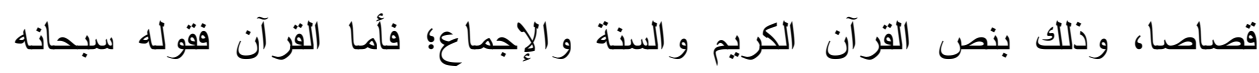

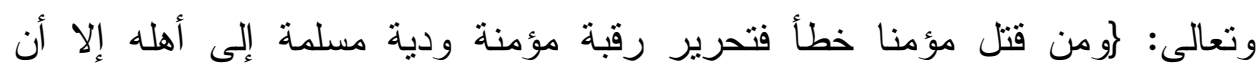

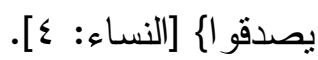

و وأما السنة فما روي أن النبي صلى اله عليه وسلم كتب إلى أهل اليمن كتابا فيه

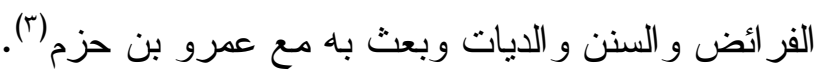

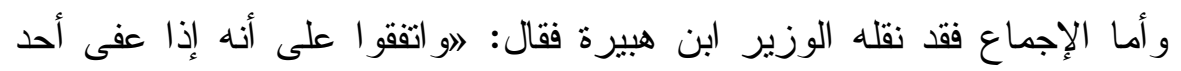

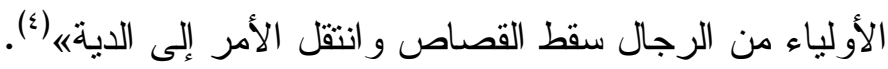

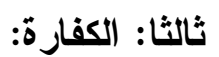

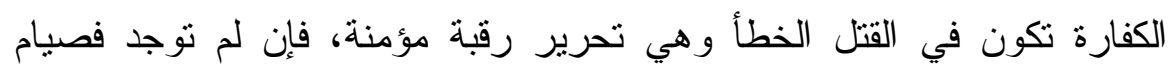

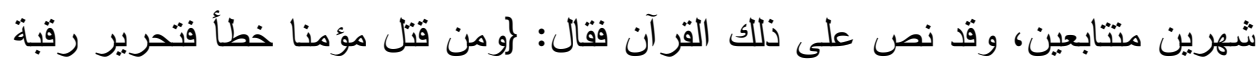

(') الدر الدختار شرح تتوير الأبصار وجامع البحار، لمحمد بن علي الحصكفي، تحقيق: عبد المنعم خليل إبر اهيم، دار

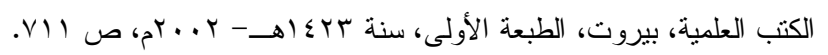

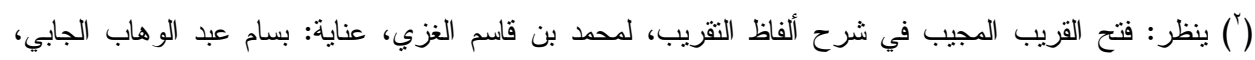

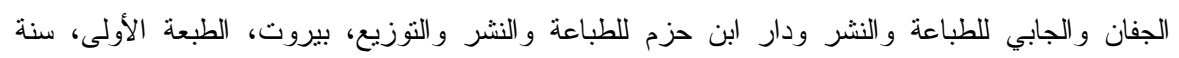
TrO

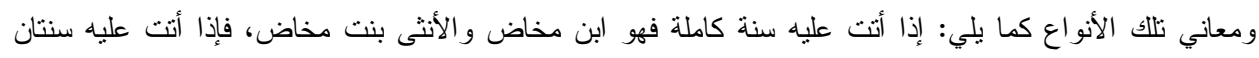

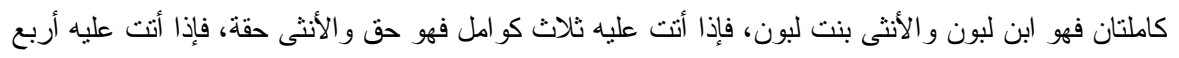

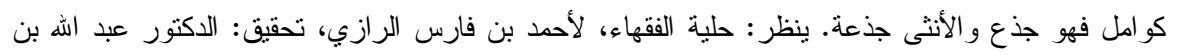

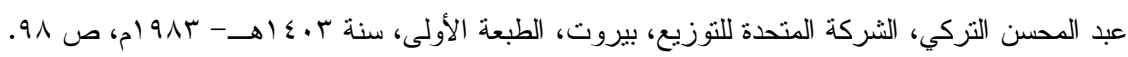

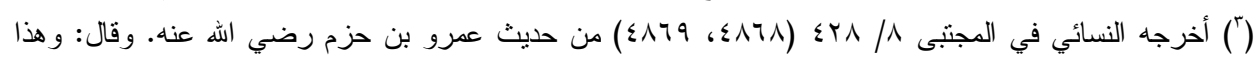

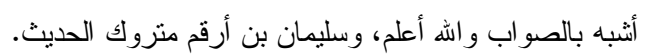

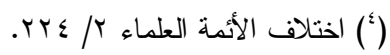


مؤمنة ودية مسلمة إلى أهله إلا أن يصدقو أفإن كان من قوم عدو لكم وهو مؤمن

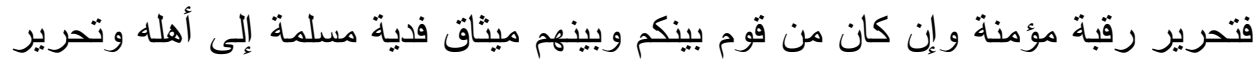

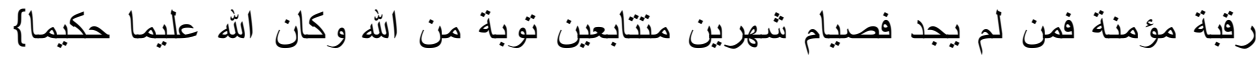

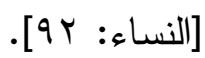

ولكن ثمة تساؤل لا بد أن يُطرح هنا، وهو إذا كانت الكفارة تجب في القتل الخطأ

فهل يقاس على ذلك القتل العمد فتجب فيه الكفارة؛ لنه و الجو اب عن هذا بأن الفقهاء اختلفو ا في ذلك على فلى قولين: القول الأول: أنها لا تجب في القتل العمد مطلقا. وهذا قول جمهور الفقهاء من

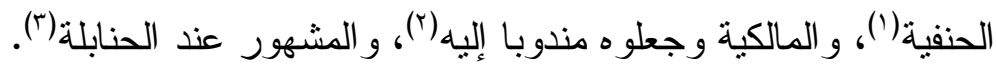
و استدل أصحاب هذا القول بمفهوم قوله سبحانه وتعالى: (رومن قتل مؤمنا خطأ

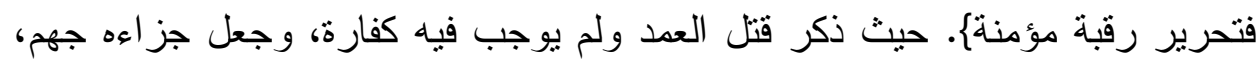
فمفهومد أنه لا كفارة فيه( وبما روي أن الحارث بن سويد بن الصامت قتل رجلا فأوجب النبي صلى اله عليه وسلم القود ولم يوجب كفارة)(0). القول الثاني: أنها تجب في القتل العدد كما في القتل الخطأ. وهذا قول

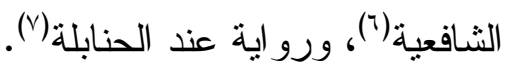

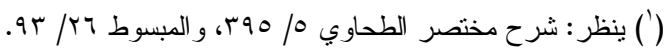

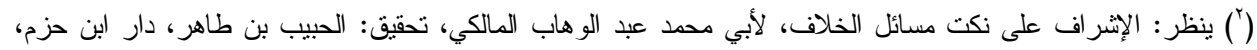

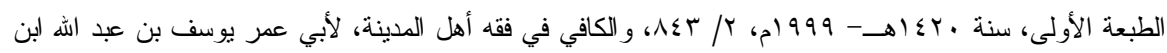

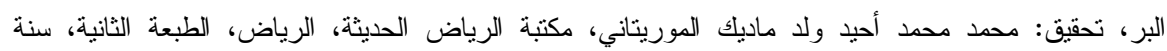

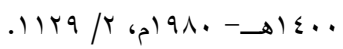

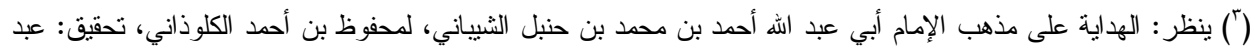

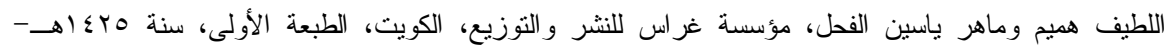

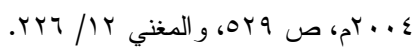

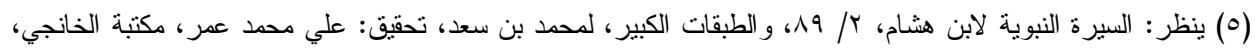

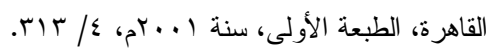

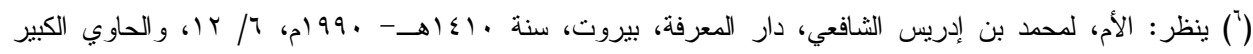

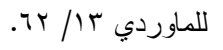

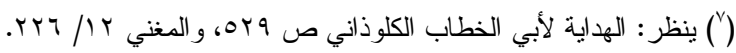


و استدل أصحاب هذا القول بقوله و اتلة بن الأسقع قال: أتينا النبي صلى الله عليه وسلم بصاحب لنا قد أوجب بالقتل، فقال: »اعتقوا عنه رقبة، يعتق الله تعالى بكل عضو منها عضوا منه من النار "('). وبقياس قتل العدد على قتل الخطأ بايجاب الكفارة. رابعا: التعزير:

التعزير : هو عقوبة غير مقدرة شرعا، تجب حقا لله أو لآدمي، في كل معصية فعلية أو قولية ليس فيها حد و لا كفارة غالبا، فهو تأديب دون الحد (ب).

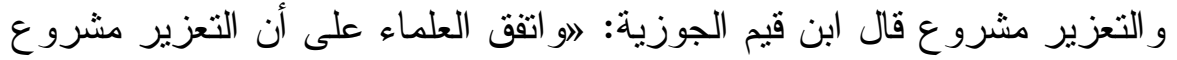
في كل معصية ليس فيها حد، وهي نوعان: ترك واجب أو فعل محرم، فمن تزك كاء

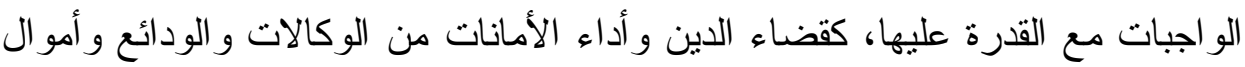
اليتامى و الوقوف و الأمو ال السلطانية ورد الغصوب و المظالم فإنه يعاقب حتى يؤديها،

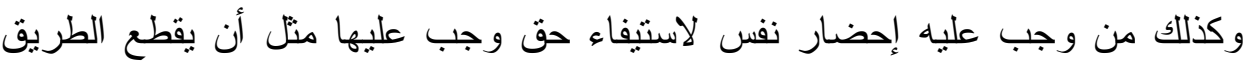

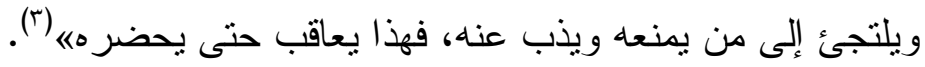

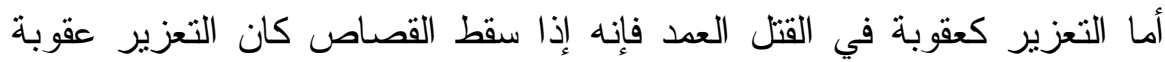
بديلة عنه، ولكن هل هذا التعزي و اجب أو جائز؟ اختلف الفقهاء فيه على قولين: القول الأول: أنه يجب هنزير القاتل العدد إذا لم يقتص منه، و العقوبة هي جلد مائة وحبس سنة. و هذا قول المالكية. القول الثاني: لا يجب التعزي في القتل العدد و إنما يفوض الأمر للحاكم يفعل ما ير اه مناسبا للمصلحة(؟). لألئ.

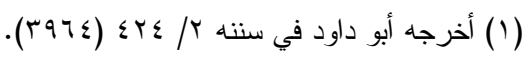

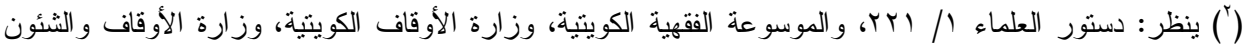

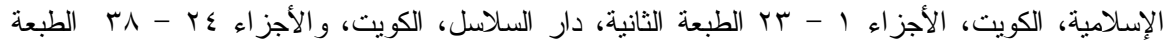

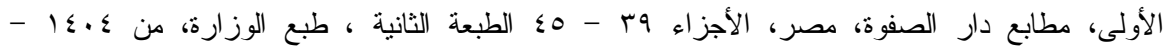

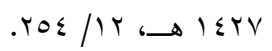

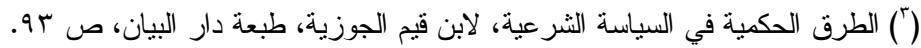

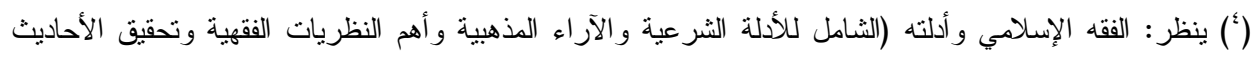

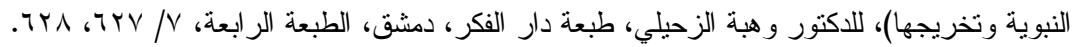


ثانيا: القتل الشبه عمد:

يقصد بالقتل الثبه عمد بأن يتعدد القاتل ضرب المقتول بغير محدد وغيره، دون

أن يقصد قتله (') - (1)

يتبين من تعريف القتل شبه العمد أنه لا بد لكي يكون القتل شبه عمد أن يتوفر

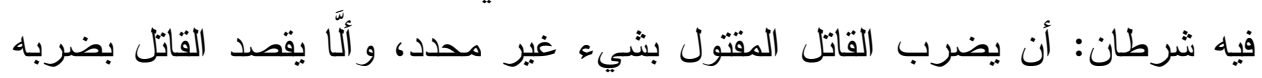
المقتول قتله. أما عن عقوبة القتل شبه العمد فهي كما يلي: أولا: الاية المغلظة:

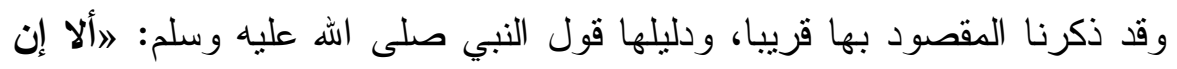
دية الخطأ شبه العمد ما كان بالسوط والعصا مائة من الإبل: منها أربعون في بطونها

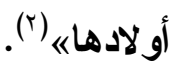

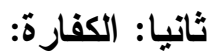

عرفنا الكفارة من قبل، وذكرنا أنها عتق رقبة مؤمنة فإن لم يجد فصيام شهرين متتابعين، كما ورد النص القر آني الذي أوردناه آنفاء

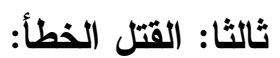

ويقصد به القتل الذي لم يكن عمدا ولا شبه عمد، أي أن ما أصابه فقتله مما لم

$$
\text { يُرِده، و إنما أر اد غيره(r). }
$$

وعقوبته تتمثل في: الدية و الكفارة، بدليل قوله سبحانه وتعالى: كومن قتل مؤمنا

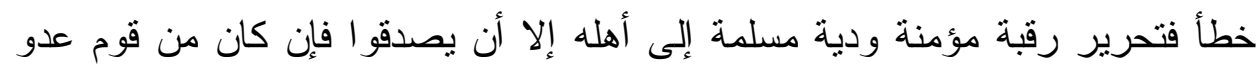

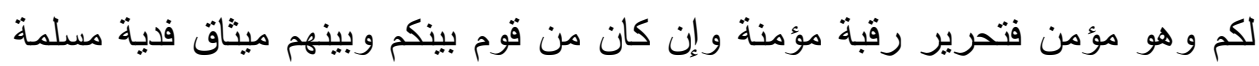

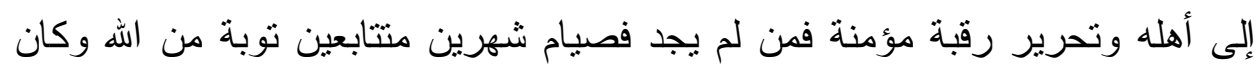
الله عليما حكيماج [النساء: و 9$]$

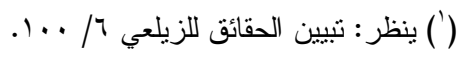

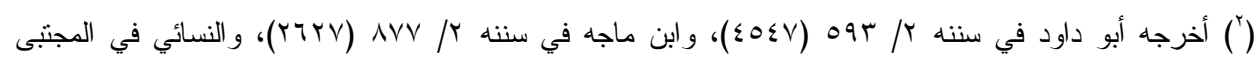

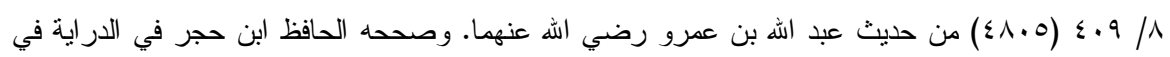

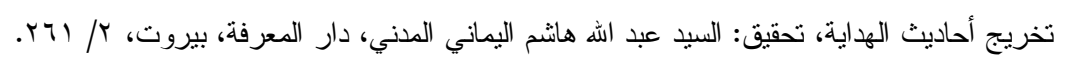

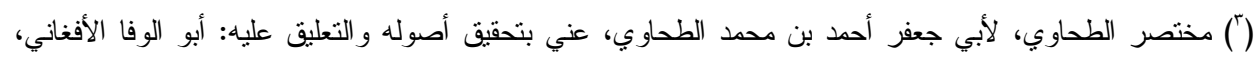

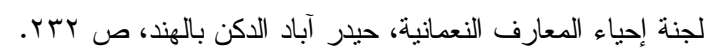


وأيضا من الجنايات على جسم الإنسان الجناية على ما دون النفس يكون

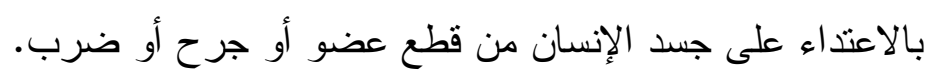

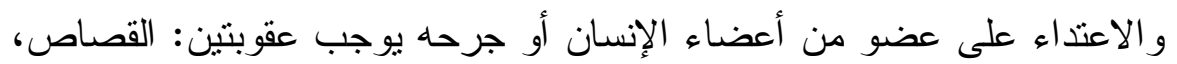

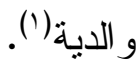

وكذللك من الجنايات التي تقع في جسم الإنسان هي قتل الجنين في بطن أمه سو اء بالاعتداء أو الإجهاض، وتكون عقوبته دية جنين (r). وثمة تساؤل مهم لا بد من الإجابة عنه، وهو من بملك سلطة سلة إقامة العقوبات

الثر عية؟

هذا التساؤل آثرت طرحه و الإجابة عنه؛ لأن كثير ا من الإهاربيين أعطى السلطة

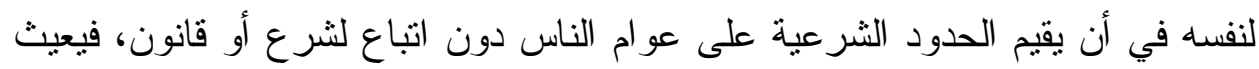
في الأرض فسادا وتقتيلا، و لا يفرق بين أحد وكأن الأمر عنده امتثلا لأمر الله سبحانه وتعالى وتحكيم شر عه بإقامة الحدود.

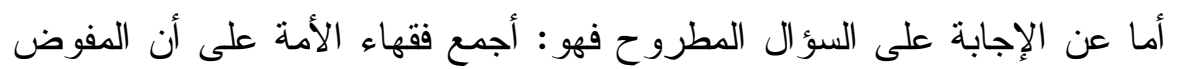

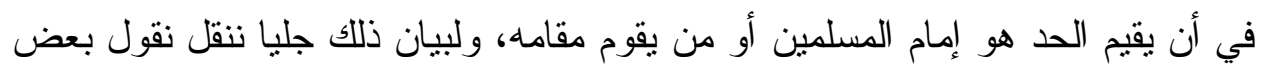
فقهاء المذاهب الأربعة في ذللك: قال أبو بكر الجصاص من الحنفية: الاو الأصل في ذلك عندهم أن الحدود تتعلق إقامتها بالإمام أو بمن يقوم مقامه فيهاه (r).

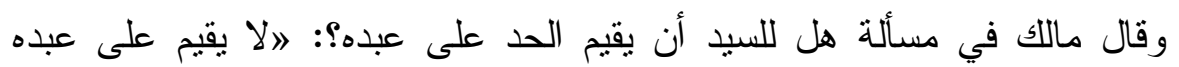

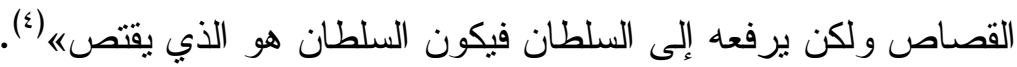




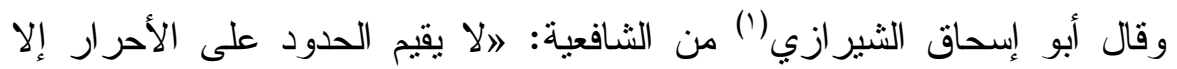

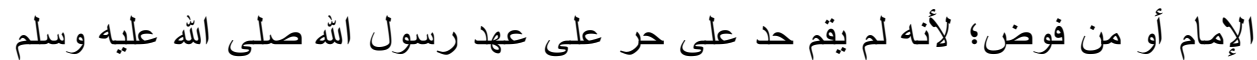
إلا بإذنه، و لا في أيام الخلفاء إلا بإذنهمها (r)

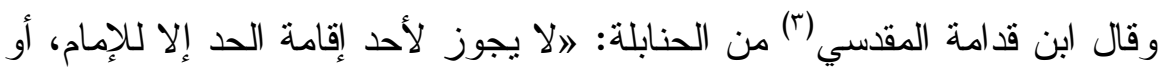

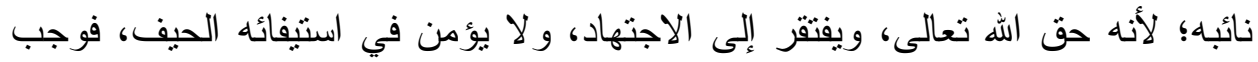

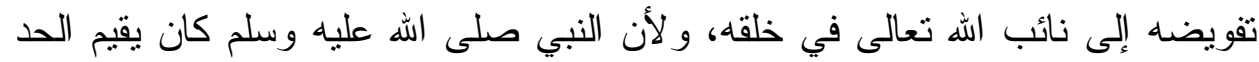

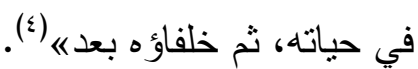
فتبين من هذه النقول أن الإمام هو صاحب النهام السلطان المطلق في إقامة الحدود وتتفيذها على أرض المسلمين، فإن لم يكن الإمام فعليه أن يوكل من يقوم مقامه في إقامته وتتفيذها، و هذا القائم مقام الإمام في كثثير من التشريعات يكون القاضي.

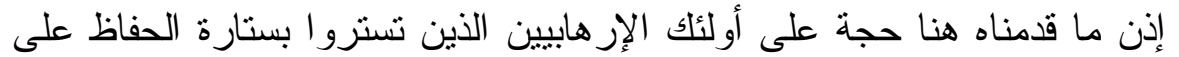

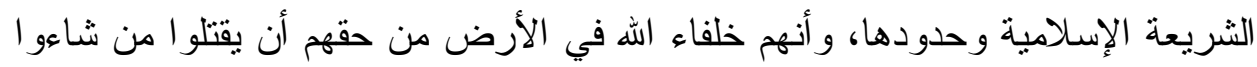

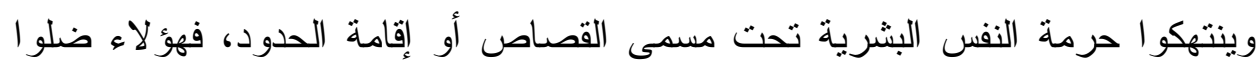
و أضلو ا كثير ا من الجهال الذين خدعو هم باسم الدين.

(') هو: إير اهيم بن علي بن يوسف، جمل الدين أبو إسحاق الثيرازي الثافعي الفيروزآبادي، انتهت إليه رئاسة

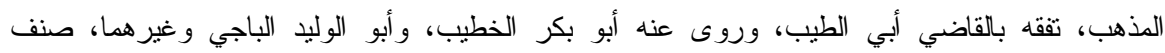

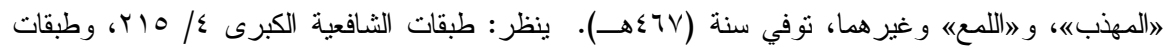

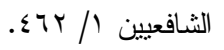

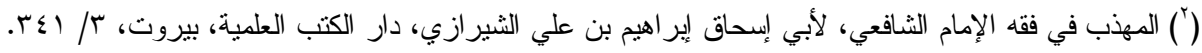

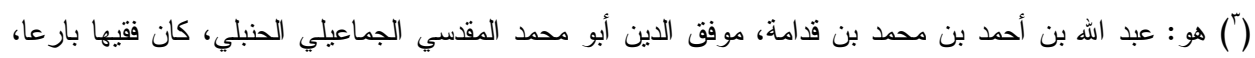

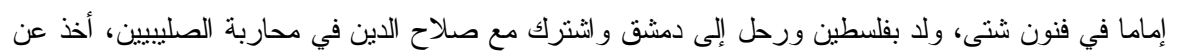

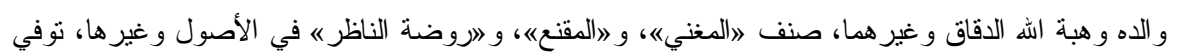

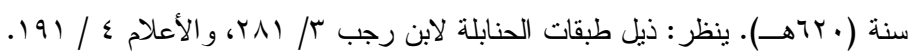

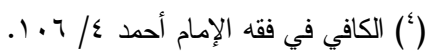




\section{المبحث الر ابع}

\section{حفظ النسل والعرض وأثره في تحريم الإرهاب}

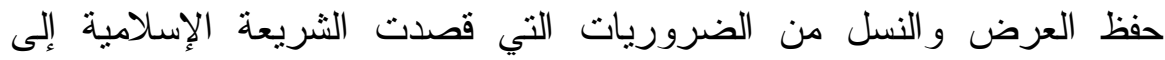

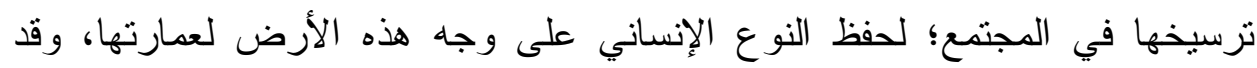

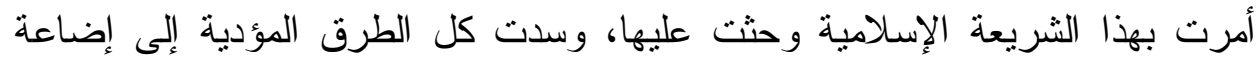

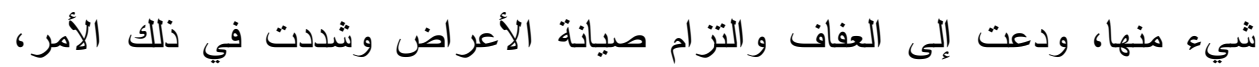

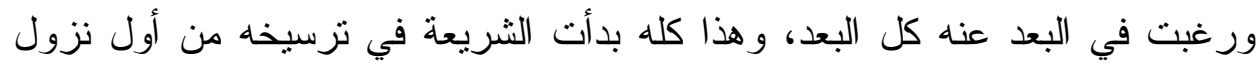
الوحي على النبي صلى الله عليه وسلم؛ فقد هدم الإسلام كل العادات الجاهلية التي

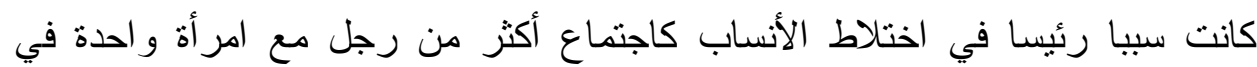
فتز ات متقاربة، فإذا حملت هذه المر أة نسبت الابن إلى أيها شاءت التهاب.

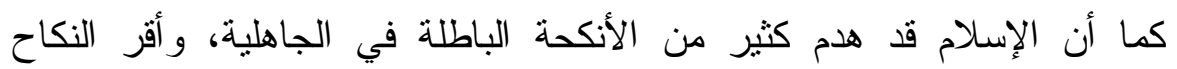
الشرعي الذي به يصان العرض ويثبت النسب، فأبطل نكاح المتعة و الشغار وغير هما.

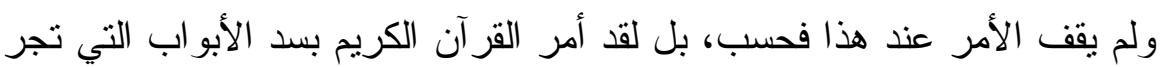

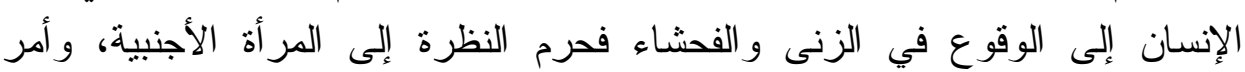
الإنسان بحفظ فرجه إلا عما أحله الله سبحانه وتعالى، فقال الله تعالى: إلى اللى للمؤمنين يغضوا من أبصار هم ويحفظو ا فروجهم ذلك أزكى لهمج [النور : . بـ].

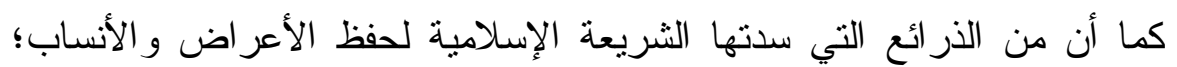
أنها حرمت الخلوة بالمر أة الأجنبية، ومخالطة المر أة للرجال ومزاحمتهم في الأماكن الأنها

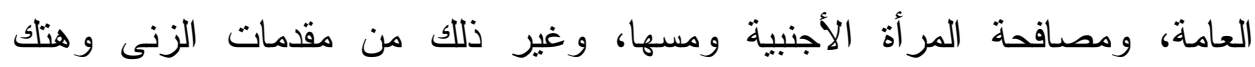

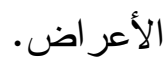

ولم تقف الثريعة الإسلامية عند تحريم هذه الأشياء فحسب، بل شرعت البدائل

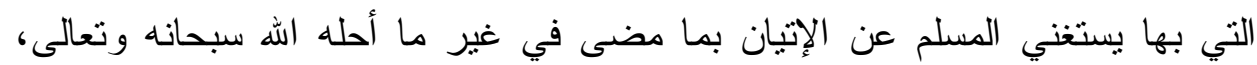

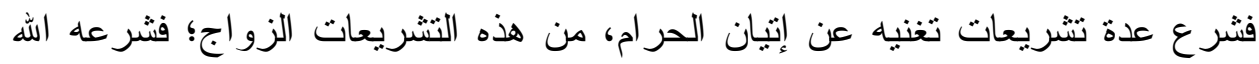

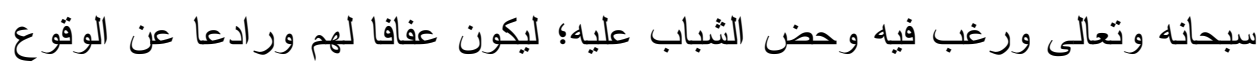

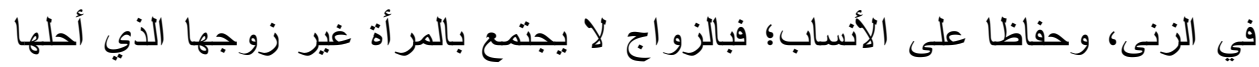

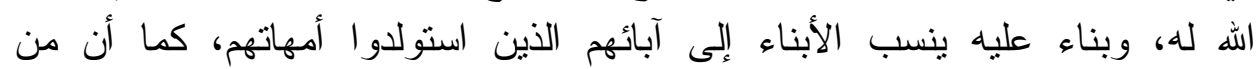

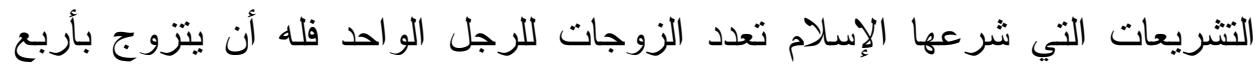

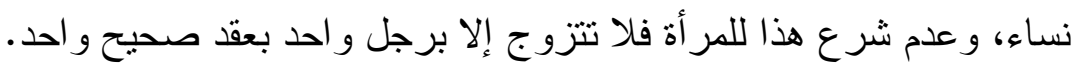




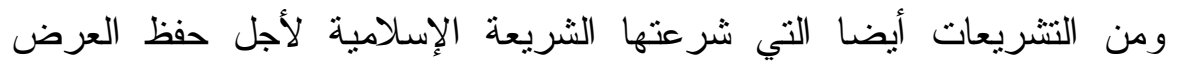
و النسل؛ إلزام الأب بتربية أبنائه و الإنفاق عليهم ورعايتهم لتوثيق رو ابط الود التئ و الألفة

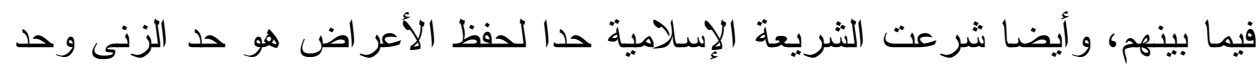
(القذف (').

وقد أدخل الثاطبي حفظ النسل و العرض تحت حفظ النفس فقال: اوقد دخل حفظ النسل في هذا القسم- حفظ النفس-، و أصوله في القر آن و السنة بينتهاه (؟). و لأجل حفظ الأعر اض و الأنساب شرع الإسلام حدين هما:

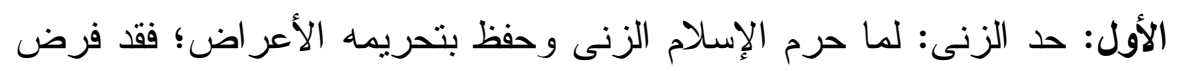

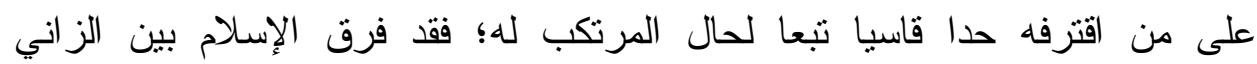

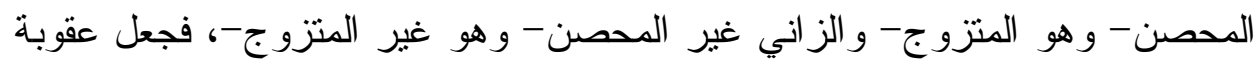

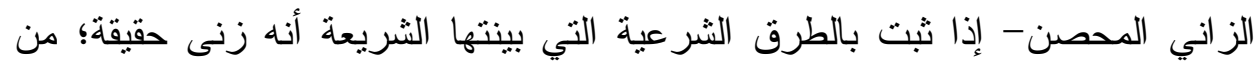

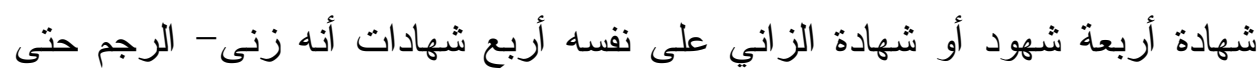
الموت، لحديث أبي هريرة رضي الله عنه قال: أتى رجل رسول الله صلى الله عليه

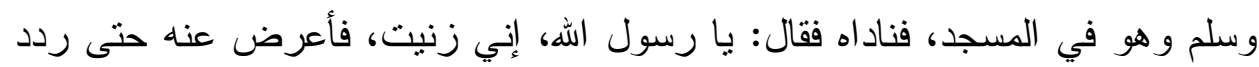

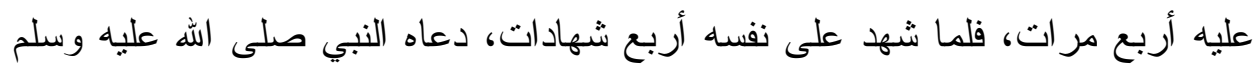

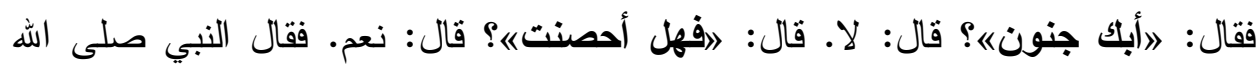

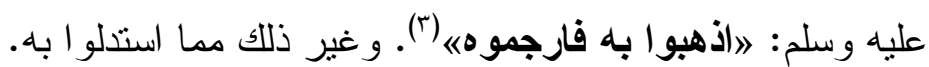

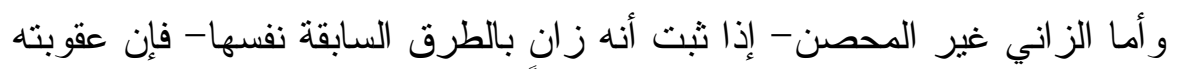

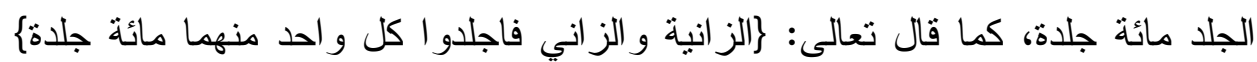

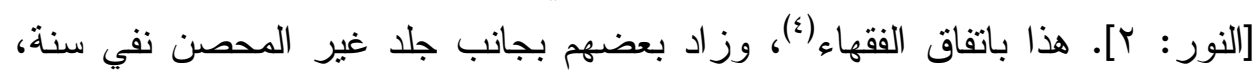

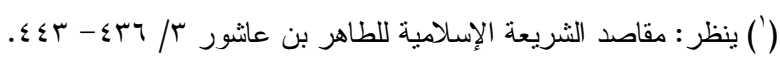

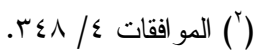

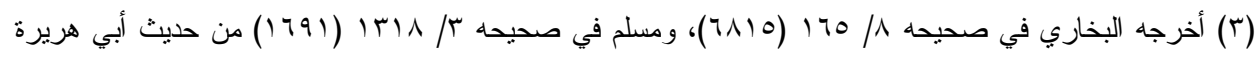

$$
\text { رضي الله عنه. }
$$

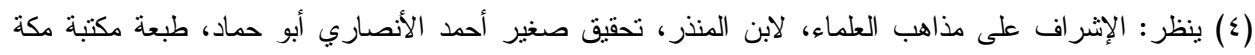

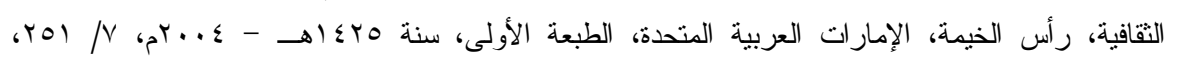

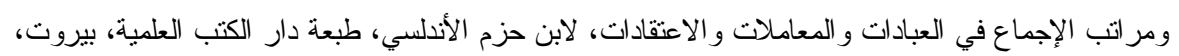


و استخل بعدة أحاديث منها حديث أبي هريرة رضي اله عنه أن النبي صلى اله عليه وسلم قضى فيمن زنى ولم يحصن بنفي عام و إقامة الحد عليه('). الثاني: حد القذف: لما كان من مقاصد الثريعة الإسلامية حفظ أعر اض اض الناس وسمعتهم حرم عليهم قذف المسلمات بالزنى وعدم العفاف، وحد القاذف بالجلد ثمانين جلدة، كما قال تعالى: كو الذين يرمون المحصنات ثم لم يأتو ا بأربعة شهداء فاجلدو هم

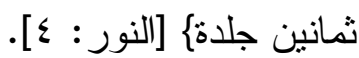
فلما ضاعت كل هذه القيم الثرعية التي أرساها الإسلام في المجتمعات لحفظ التئ الأعر اض والأنساب، أصبحنا نجد انتشار حوادث الاغتصاب وهنك الأعر اض، بل فئل

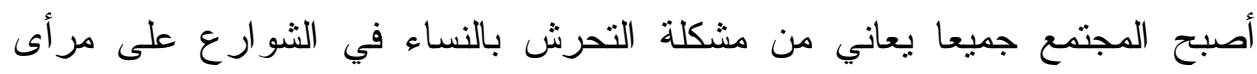

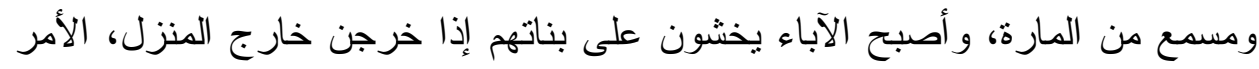
الذي تسبب في نوع من الفزع و الهلع الذي ساد المجتمع بسبب نلاءك الظواهن اهر التي انتشرت و عانت منها المجتمعات. لون لون 


\section{المبحث الخامس \\ حفظ العقل وأثره في تحريم الإرهاب}

حفظ العقل عرفه الطاهر بن عاشور بقوله: 》حفظ عقول الناس من أن يدخل عليها خلل؛ لأن دخول الخلل على العقل مؤد إلى فساد عظيم من عدم انضباط التصرف؛ فذخول الخلل عقل الفرد مفض إلى فساد جزئي، ودخوله على عقول

الجماعات و عموم الأمة أعظمه (').

وقد شرع الله سبحانه وتعالى لحفظ العقل تحريم كل ما يؤدي إلى فساده أو تغييبه كتحريم الخمر و المخدر ات وما شابهها، وقد قال الله سبحانه وتعالى: إنما يريد الثيطان أن يوقع بينكم العداوة و البغضاء في الخمر و الميسر ويصدكم عن ذكر الله وعن الصلاة

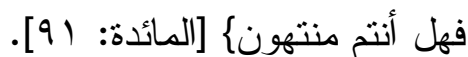

قال الواحدي(ז) عند تقسير هذه الآية: الاقال أهل المعاني: إن الثيطان يزين لهم ذلك حتى إذا سكروا وز الت عقولهم أقدموا من المكاره و المقابح على ما كانت تمنعه الته الته

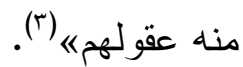

وقال أيضا عند تفسير الثق الأخير من الآية والحديث عن الصد عن ذكر الله و الصلاة: اوذللك أن من اشتخل بشرب الخمر و القمار ألهاه ذلك عن ذكر الله جل وعز ونز بالتعظيم و الثكر على آلائه و عن عبادته ه( (؛). و أكد النبي صلى الله عليه وسلم على تحريم ما أسكر؛ صيانه وعن عائه للعقل من التغييب

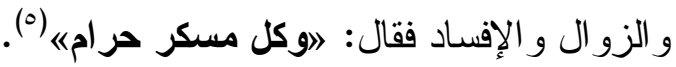
و أما بالنسبة لعقبة حد السكر وتغييب العقل فهي الجلد، ولكن جاء الأمر بجلد

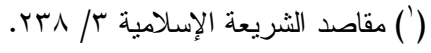

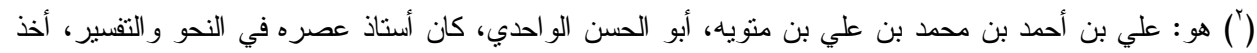

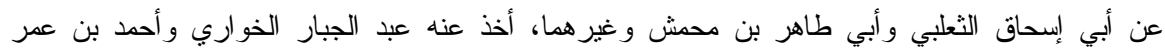

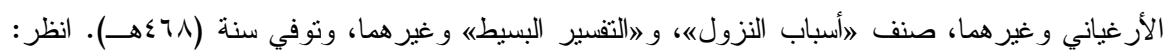

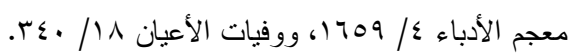

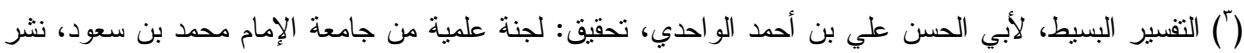

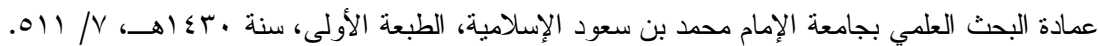

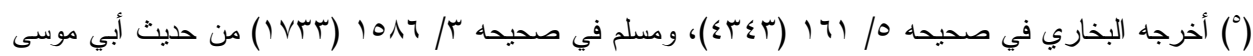
الأشعري رضي الله عنه. 


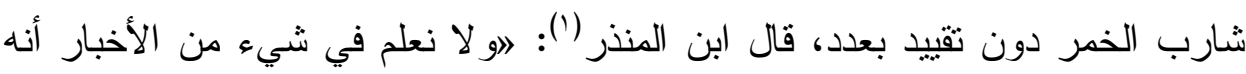

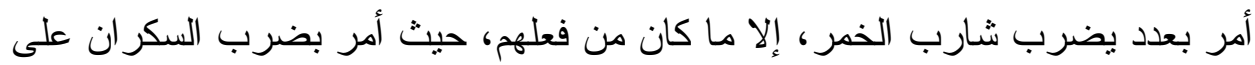

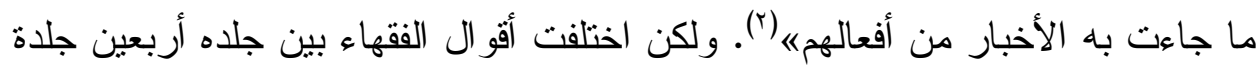

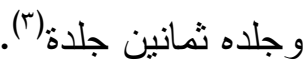

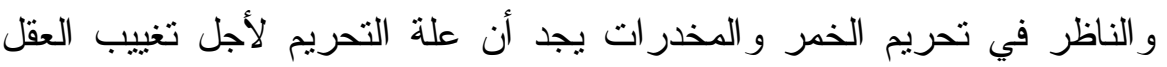

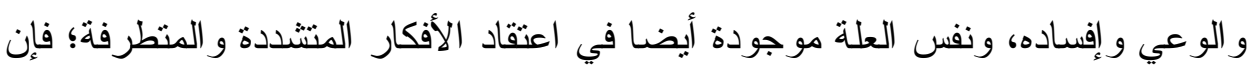

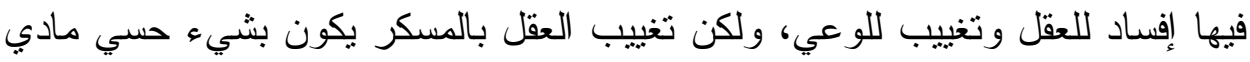

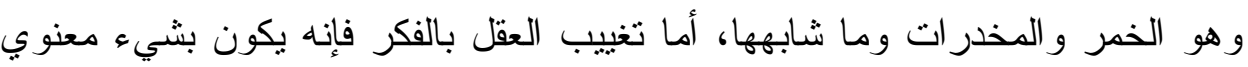
و هو الأفكار المتتددة و المتطرفة، و التطرف و الإزهاب من ذلك التغييب المعنوي.

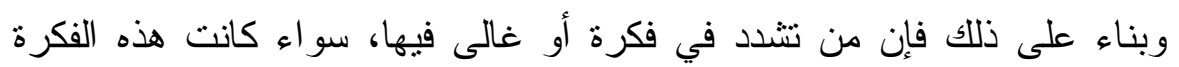

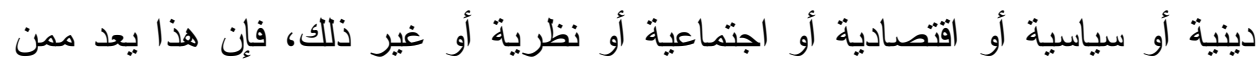

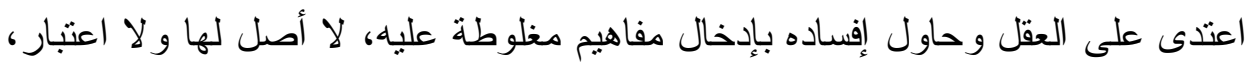

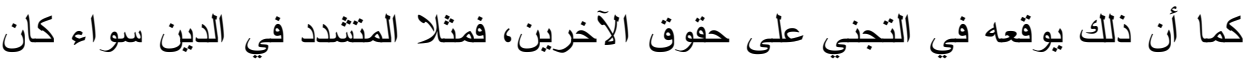
هذا التشدد في الاعتقاد الذي أساسه التوحيد، أو في العبادة التي التي أساسها الأحكام فئلاف

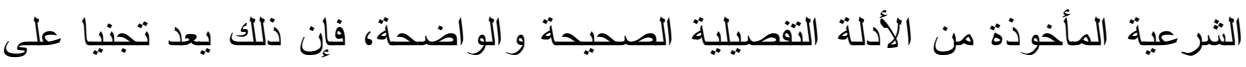
الله سبحانه وتعالى وشرعه، كما يعد أيضا تجنيا على عقول الآخرين الذين يحاول

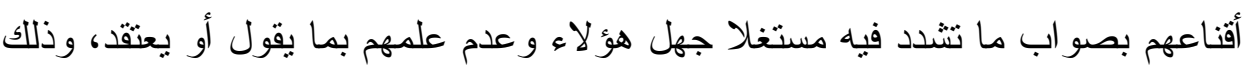

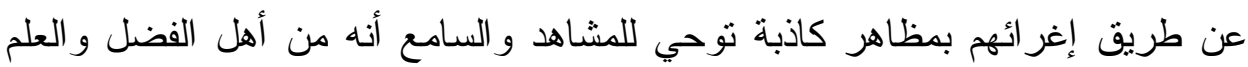

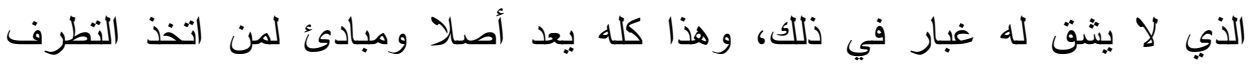
و الإرهاب منهجا له في حياته.

(') هو : محمد بن إير اهيم بن المنذر النيسابوري، من كبار الفقهاء المجتهين ولم يكن مقلدا لأحد، كان إماما مجتهدا حافظا

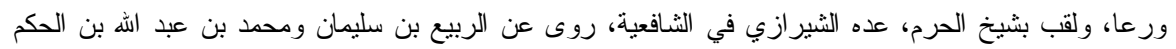

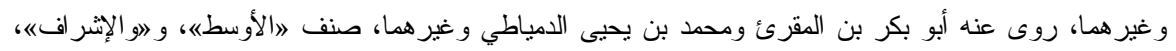

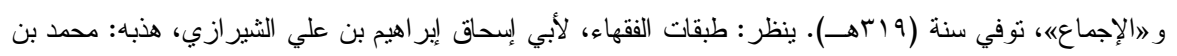

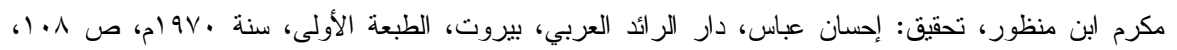

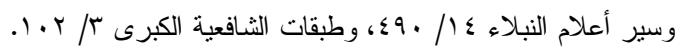


المبحث السادس

\section{حفظ المال وأثره في تحريم الإرهاب}

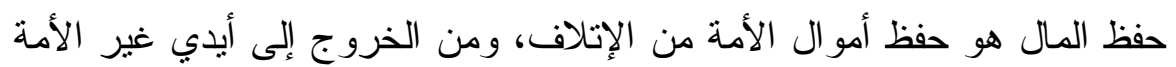
بدون عوض، وحفظ أجزاء المال المعتبرة عن التلف بدون عوض، وحفظ الإن وهن الأموال الفردية يؤول إلى حفظ مال الأمة، وباه يحصل حصول المال الهعثة عن الكل بحصول أجزائه('). و أصل مشروعية حفظ الأموال في الإسلام قوله سبحانه وتعالى: إيا أيها الذين

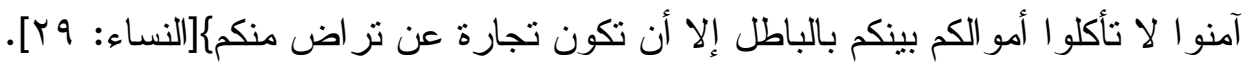
وقوله صلى الله عليه وسلم في خطبة حجة الوداع: "إن دماعكم و أموالكم عليكم حرام كحرمة يومكم هذا في شهركم هذا في بلدكم هذاه(؟). وقوله أيضا: 》الا يحل مال

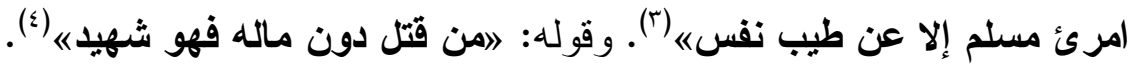

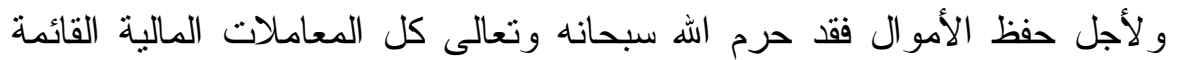

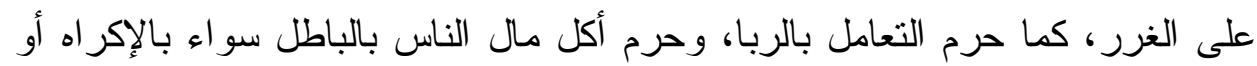

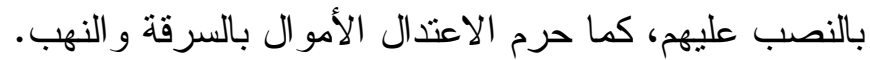

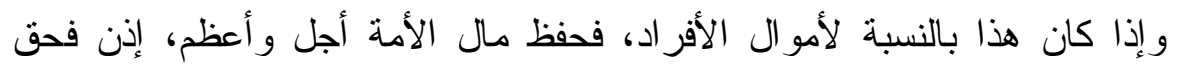

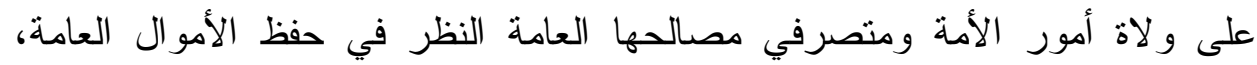

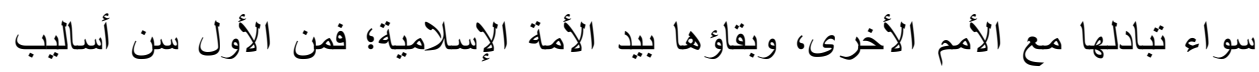

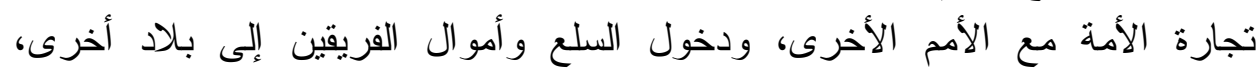

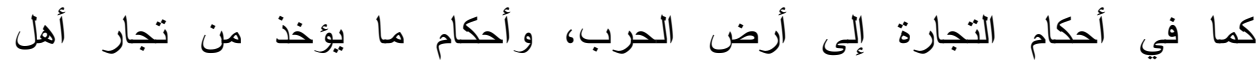

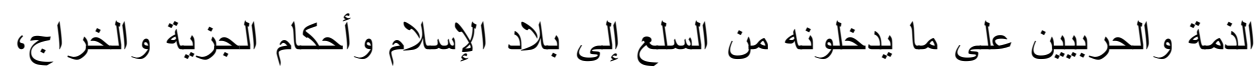

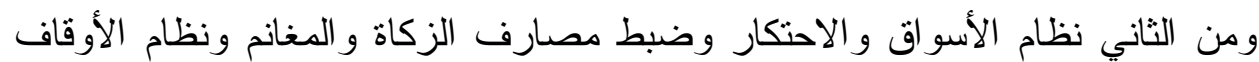

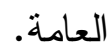

وحق على من ولي مال أحد أن يحفظه، وقد قال الله تعالى: رو لا تؤتو السفهاء

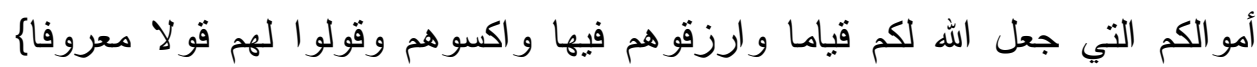

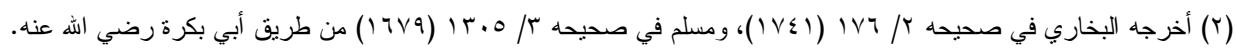

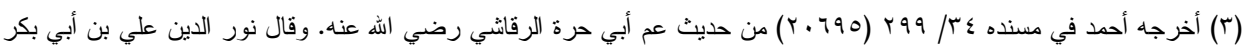

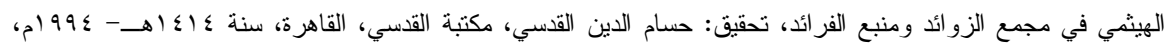

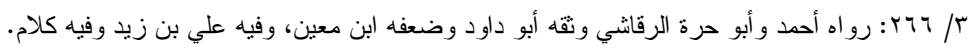

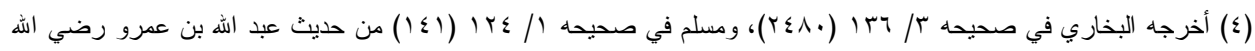


[النساء: 0]. وقال أيضا: فإن آنستم منهم رشدا فادفعوا إليهم أمو الهم ولا تأكلوها

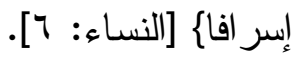

وحق على كل أحد احترام مال غيره، ولذللك تقرر غرم المتلفات وجعل سببها

الإتلاف (')

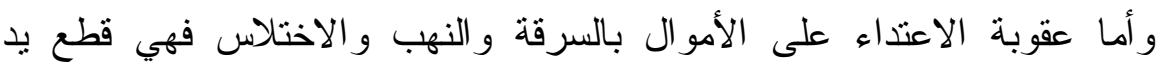

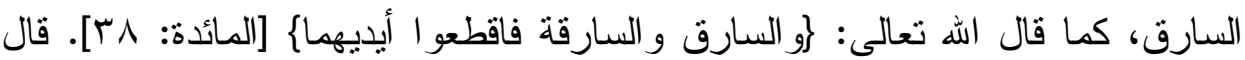
الوزير ابن هبيرة: او اتفقو العلى وجوب قطع السارق والسارقة في الجملة إذا جمعا

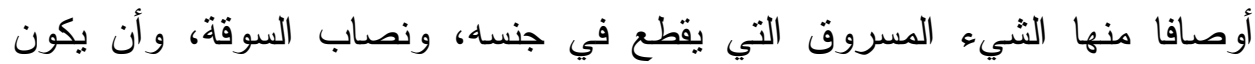

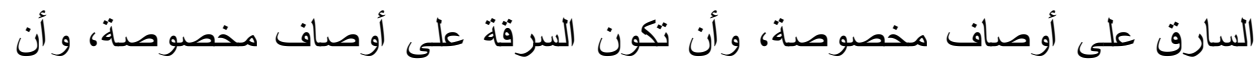

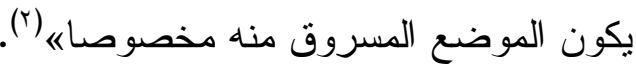

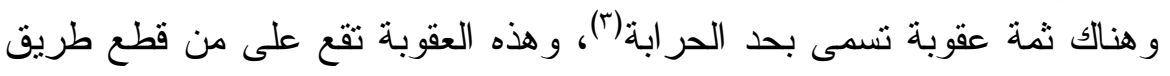

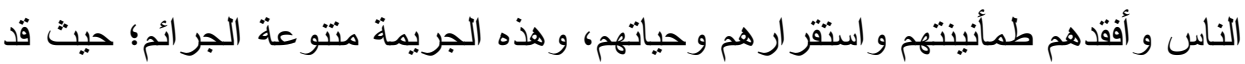

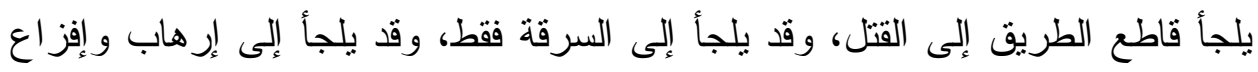

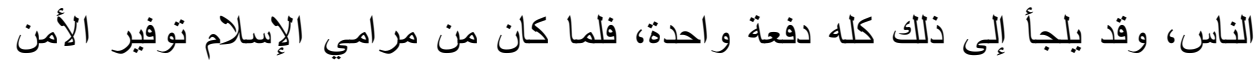

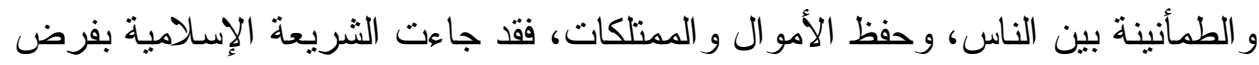
عقوبة هي حد الحرابة على قاطع الطريق ومن شاركه في جريمته، كما قال تعالى:

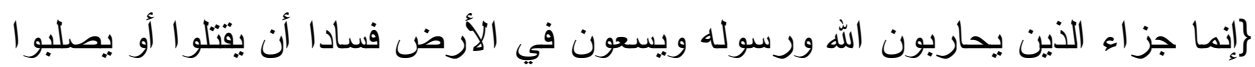

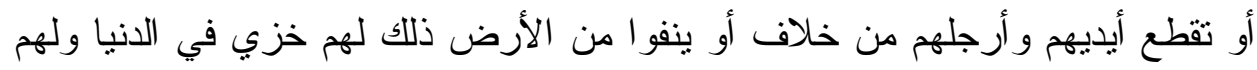

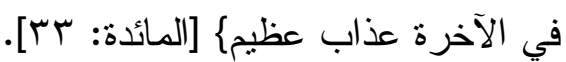
ومعلوم أن الاعتداء على الأموال بسرقتها وأكلها بالباطل وقطع الطريق عليهم

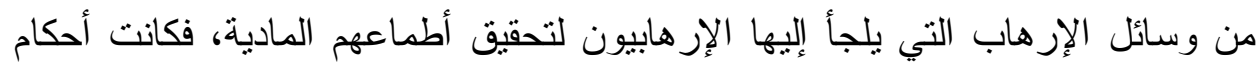

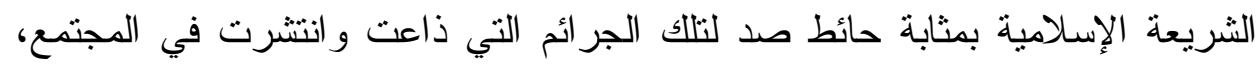
مما يدل على أن الإسـام برئ من أبي عنف أو إرهاب يمارس في المجتمعات، ويكون

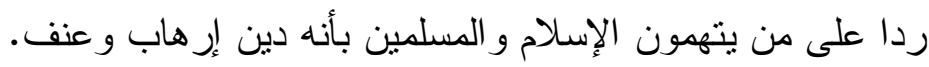

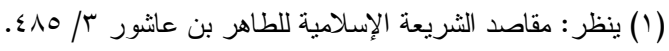

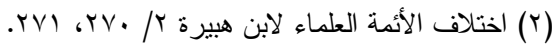

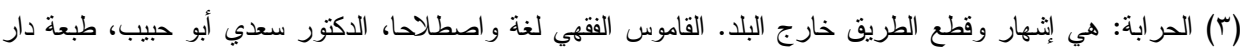

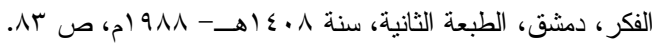




\section{الخاتمة}

الحمد الله والصلاة والسلام على رسول الله صلى الله عليه وسلم وآله وصحبه وسلم.

بعد أن اطلعنا على الفكر المقاصدي في مواجهة الإزهاب، أحاول أن ألقي الضوء على أهم النتائج التي توصلت إليها خلال بحثي في هذا الموضوع، وهذه النتائج هي:

1- الأحكام في الثريعة الإسلامية جاءت لجلب المصلحة ودرء المفسدة؛ وذلك بتحقيق الضروريات المقاصدية الخمسة. r- مصطلح الإرهاب اختلف في تحديده، وهو في أصله ير ادف عدة مصطلحات كالغلو و التشدد ومجاوزة الحد. r- الشريعة الإسلامية ونصوصها الشرعية حثت الأمة على التزام الأخلاق الثاق الحميدة، ونبذ كل الأخلاق و العادات الذميمة.

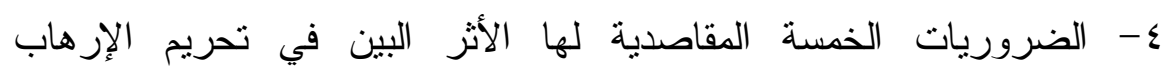
ومحاربته، و الابتعاد به عن إلصاقه بالإسلام. وصلى الله على محمد و على آله وصحبه وسلم تسليما كثير ا. 